\title{
Long Term Soil Gas Monitoring as Tool to Understand Soil Processes
}

\author{
Martin Maier*(D), Valentin Gartiser, Alexander Schengel and Verena Lang
}

Department Soil and Environment, Forest Research Institute Baden-Württemberg, 79100 Freiburg, Germany; valentin.gartiser@forst.bwl.de (V.G.); Alexander.Schengel@forst.bwl.de (A.S.); Verena.Lang@forst.bwl.de (V.L.)

* Correspondence: martin.maier@forst.bwl.de

Received: 29 October 2020; Accepted: 30 November 2020; Published: 3 December 2020

Featured Application: Extensive long-term monitoring of greenhouse gases in soils. The mechanically simple and robust design makes the set-up an efficient, versatile, and reliable tool for soil gas monitoring, especially in forest soils. It can also be included in other routine monitoring networks with limited investment and relatively low additional labor costs.

\begin{abstract}
Soils provide many functions as they represent a habitat for flora and fauna, supply water, nutrient, and anchorage for plant growth and more. They can also be considered as large bioreactors in which many processes occur that involve the consumption and production of different gas species. Soils can be a source and sink for greenhouse gases. During the last decades this topic attracted special attention. Most studies on soil-atmosphere gas fluxes used chamber methods or micro-meteorological methods. Soil gas fluxes can also be calculated from vertical soil gas profiles which can provide additional insights into the underlying processes. We present a design for sampling and measuring soil gas concentration profiles that was developed to facilitate long term monitoring. Long term monitoring requires minimization of the impact of repeated measurements on the plot and also minimization of the routine workload while the quality of the measurement needs to be maintained continuously high. We used permanently installed gas wells that allowed passive gas sampling at different depths. Soil gas monitoring set ups were installed on 13 plots at 6 forest sites in South West Germany between 1998 and 2010. Until now, soil gas was sampled monthly and analysed for $\mathrm{CO}_{2}, \mathrm{~N}_{2} \mathrm{O}, \mathrm{CH}_{4}, \mathrm{O}_{2}, \mathrm{~N}_{2}, \mathrm{Ar}$, and $\mathrm{C}_{2} \mathrm{H}_{4}$ using gas chromatography. We present typical time series and profiles of soil gas concentrations and fluxes of a selected site as an example. We discuss the effect of different calculation approaches and conclude that flux estimates of $\mathrm{O}_{2}, \mathrm{CO}_{2}$ and $\mathrm{CH}_{4}$ can be considered as highly reliable, whereas $\mathrm{N}_{2} \mathrm{O}$ flux estimates include a higher uncertainty. We point out the potential of the data and suggest ideas for future research questions for which soil gas monitoring would provide the ideal data basis. Combining and linking the soil gas data with additional environmental data promises new insights and understanding of soil processes.
\end{abstract}

Keywords: environmental monitoring; soil gas; soil gas profile; soil respiration; carbon dioxide; methane; nitrous oxide

\section{Introduction}

\subsection{Why Soil Gases?}

Soils provide many functions as they represent the base of agricultural production and terrestrial ecosystem productivity. Soils can be considered as large bioreactors. They store and provide water, nutrients, and anchorage to plants, which are able to assimilate these nutrients and additionally carbon (C) by photosynthesis. Soils not only provide the essential base for a terrestrial habitat of plants, 
but also for fauna, fungi, and microbes. The latter contribute, evolve and constitute together with the physico-chemical soil structure the function of a large bioreactor, with its specific processes and properties, and its fluxes of energy and matter [1,2]. Many processes occurring in soils involve the consumption and production of different gas species [3]. Studying soil gas concentrations and soil gas fluxes can help us to understand and quantify the underlying processes and functions.

In recent years, studies of carbon dioxide $\left(\mathrm{CO}_{2}\right)$, methane $\left(\mathrm{CH}_{4}\right)$ and nitrous oxide $\left(\mathrm{N}_{2} \mathrm{O}\right)$ and the role of soils as sinks or sources of these greenhouse gases (GHG) have become particularly important $[3,4]$. However, other gas species also play an important role in the soil. For example, oxygen $\left(\mathrm{O}_{2}\right)$ is essential for living roots, this means the soil must be well aerated, or in case of waterlogged sites, plants must develop strategies to supply $\mathrm{O}_{2}$ to their roots as it is known for reeds (Phragmites spec.) and rice plants (Orica spec.). Soils can also be a source or sink of other gases such as hydrogen $\left(\mathrm{H}_{2}\right)$, ethylene $\left(\mathrm{C}_{2} \mathrm{H}_{4}\right)$ and nitrous acid [5] which are important precursors of atmospheric chemistry. Sources of gases can be roots, litter and microbes [3], but also geological sources may play a role [6].

Most soil gas research focused on $\mathrm{CO}_{2}, \mathrm{CH}_{4}$, and $\mathrm{N}_{2} \mathrm{O}$, which are the most important anthropogenic GHG. They are co-responsible for global climate change [4] and linked into the global $\mathrm{C}$ and nitrogen (N) cycles. Atmospheric concentration of $\mathrm{CH}_{4}$ has risen from preindustrial $702 \mathrm{ppb}$ to $1872 \mathrm{ppb}$ in 2020, and $\mathrm{N}_{2} \mathrm{O}$ concentration increased by a factor of 1.2 to $333 \mathrm{ppb}$, while atmospheric $\mathrm{CO}_{2}$ increased from preindustrial $278 \mathrm{ppm}$ to $409 \mathrm{ppm}$ in 2020 [7]. Even though atmospheric concentrations and soil-atmosphere fluxes of $\mathrm{N}_{2} \mathrm{O}$ and $\mathrm{CH}_{4}$ are much smaller than the concentration and fluxes of $\mathrm{CO}_{2}$ their relevance is substantial due to the higher radiative forcing of $\mathrm{N}_{2} \mathrm{O}$ and $\mathrm{CH}_{4}$ molecules [4]. Soil gas concentrations can differ substantially from atmospheric concentrations, and can be both, higher and lower than atmospheric concentrations, depending on the prevailing process in the soil.

Soil $\mathrm{CO}_{2}$ emissions mainly result from heterotrophic and autotrophic respiration in the soil, i.e., from microbes, soil fauna and roots, and amount up to more than $75 \%$ of the carbon that is assimilated by plants during photosynthesis [8]. Soil $\mathrm{CO}_{2}$ emissions can deviate temporarily from soil respiration e.g., after heavy rainfall when soil $\mathrm{CO}_{2}$ is blocked in the soil pore space for some time [9]. Soil generally acts as a source of $\mathrm{CO}_{2}$, even if the soil is a net sink for $\mathrm{C}$ due to plant growth and $\mathrm{C}$ fixation as recalcitrant soil organic matter. Studying soil $\mathrm{CO}_{2}$ concentrations and fluxes can help to understand how environmental changes affect stability of soil organic matter [10] and how plants respond to such changes [11]. Increasing temperatures due to global climatic change might mobilize carbon stored in the soil, yet, increases of plant-derived carbon inputs to soils might exceed these increases in decomposition [12].

Soils can be a source of and sink for $\mathrm{CH}_{4}[3,13,14]$. Methanogenesis is a strictly anaerobic process [5], but can occur as well in aerated soils, where oxygen-deficient zones can exist within water-saturated soil aggregates [15]. Waterlogged sites such as peat and wetlands are often net sources of $\mathrm{CH}_{4}$ and have very low $\mathrm{O}_{2}$ concentrations and high $\mathrm{CH}_{4}$ concentrations in the soil profile. Well aerated upland soils in forests are usually $\mathrm{CH}_{4}$ sinks where methanotrophy dominates over methanogenesis [16-18].

Soils can also be a source of and sink for $\mathrm{N}_{2} \mathrm{O}$, even though research mainly focused on $\mathrm{N}_{2} \mathrm{O}$ production and emission of soils. However, there is evidence that soils can consume $\mathrm{N}_{2} \mathrm{O}$ [19]. This can also be deduced from sub-atmospheric concentrations that can be found in soils [16]. Net $\mathrm{N}_{2} \mathrm{O}$ uptake rates of soils, however, are usually low compared to reported potential emissions. $\mathrm{N}_{2} \mathrm{O}$ production mainly occurs within soil aggregates in sub- or anoxic zones [15]. $\mathrm{N}_{2} \mathrm{O}$ is a by-product during nitrification and denitrification [20]. $\mathrm{N}_{2} \mathrm{O}$ can be reduced to $\mathrm{N}_{2}$ during microbial denitrification in soils which is eventually emitted to the atmosphere. Resulting $\mathrm{N}_{2}$ fluxes and fluctuations in $\mathrm{N}_{2}$ soil concentration due to production of $\mathrm{N}_{2}$ are very small compared to the atmospheric background $\mathrm{N}_{2}$ concentrations $(78 \%)$ so that they cannot be detected by normal means due to technical restrictions. A laboratory methodology called barometric process separation (BaPS) [21] theoretically allows accounting for the small changes associated with the production of $\mathrm{N}_{2}$ (and $\mathrm{N}_{2} \mathrm{O}, \mathrm{O}_{2}, \mathrm{CO}_{2}$ ). Yet, large methodological uncertainties remain regarding the dissolution of gases in soil water and the 
accuracy of the concentration measurements of $\mathrm{CO}_{2}$ and $\mathrm{O}_{2}$. The current state of the art methodology to quantify $\mathrm{N}_{2}$ fluxes uses isotopically labelled nitrate as $\mathrm{N}$ source [22], which is only used for short-term studies and not for long-term monitoring.

$\mathrm{C}_{2} \mathrm{H}_{4}$ is a flammable gas whose atmospheric concentrations are usually negligible outside cities and industrial areas. It has great ecological significance because it is a powerful phyto hormone, which affects ripening, flowering, senescence and root growth [23]. The so-called triple response observed for roots exposed to elevated $\mathrm{C}_{2} \mathrm{H}_{4}$ concentrations involves reduction in elongation, swelling of the hypocotyl, and a change in the direction of growth [24]. $\mathrm{C}_{2} \mathrm{H}_{4}$ is produced by most plant parts, and can also be produced by microbial activity. In soil even extremely low concentrations of a few $\mathrm{ppb}$ can have a strong effect on root growth [25]. In water saturated soil $\mathrm{C}_{2} \mathrm{H}_{4}$ can accumulate and reach concentrations $>10 \mathrm{ppm} \mathrm{[26].} \mathrm{C}_{2} \mathrm{H}_{4}$ can be produced and consumed in the soil, similar to $\mathrm{CH}_{4}$ and $\mathrm{N}_{2} \mathrm{O}$. The local concentration of $\mathrm{C}_{2} \mathrm{H}_{4}$ in the soil represents the balance of production and consumption and depends on the diffusivity of the aerated soil $[25,27]$.

Soil-atmosphere gas fluxes and soil gas concentrations change over time. Soil gases are a result of different processes and respond to different drivers. The temporal evolution of concentrations and fluxes can show reactions to single events or underlie different cycles, from diurnal to seasonal cycles. Soil $\mathrm{CO}_{2}$ fluxes, for example, show strong seasonal cycles in temperate climates. This reflects the dependence on photosynthesis and decomposition of soil organic matter which both peak in summer $[8,28]$. Usually, soil $\mathrm{CO}_{2}$ fluxes also show diurnal cycles as response to diurnal temperature variations [29]. In drier and warmer climates, soil moisture can be the main driver, since decomposition of soil organic matter and photosynthesis by plants requires a minimum of water availability [30]. Similar to soil respiration, $\mathrm{CH}_{4}$ consumption can underlie diurnal and seasonal cycles [31-33]. Periods of heavy rain can strongly reduce $\mathrm{CH}_{4}$ consumption rates. Heavy rain can also turn aerated soil into temporarily waterlogged and $\mathrm{O}_{2}$ depleted soil where $\mathrm{CH}_{4}$ production occurs [34,35]. The resulting $\mathrm{CH}_{4}$ emission can appear to be seasonal if rainfall occurs regularly in the same season, but it can also appear as single event. Similarly, $\mathrm{N}_{2} \mathrm{O}$ fluxes are often dominated by peak emission events, that can be induced by temporary anoxia due to rainfall, freeze-thaw events and rewetting of dry soil [32,36], and which are especially prominent after fertilization. Elevated $\mathrm{C}_{2} \mathrm{H}_{4}$ concentrations can be found in situations when soil gas diffusivity is reduced, i.e., in compacted or waterlogged soils, where even small production rates can lead to relevant accumulation of $\mathrm{C}_{2} \mathrm{H}_{4}$ [26].

It is important to include knowledge about possible cycles or the effects of environmental drivers and adjust the measurement schedule accordingly when soil gases are investigated in studies or monitoring routines. That means e.g., that flux or concentration measurements cover the whole year evenly if seasonal cycles are to be expected, as known for $\mathrm{CO}_{2}$. It also means that measurements should always be carried out at the same time of the day when daily cycles are expected. In most cases a systematic regular schedule adapted to the respective temporal cycles is a good choice. If gas emissions are expected to be dominated by single event-related peaks, such as $\mathrm{N}_{2} \mathrm{O}$ emissions, additional measurements before, during and after such events are recommended.

Soil-atmosphere gas fluxes and soil gas concentrations not only change over time, but they also differ substantially across the scales from ecosystems to soil gas profiles. Differences in soil respiration between ecosystems and landscapes can be partly explained by plant productivity [37], land use and soil structure [14,38]. Local plot scale variability of soil respiration can be substantial [39] even at apparently homogenous sites [40]. Soil respiration seems to co-vary with $\mathrm{CH}_{4}$ consumption on the plot scale [41,42] and also within similar landscapes [43]. Soil gas profiles usually reflect the ongoing processes of production and consumption of gases in a soil [44] and can be very different between sites. A certain variability in soil gas profiles has to be considered even in apparently homogeneous soils [16], which is partly due to variability in the ongoing processes that produce or consume the gases, and partly due to the spatial variability in soil gas diffusivity [45,46]. Plot scale variability of soil gas fluxes can be different for different gas species [42]. A certain minimum number of spatial 
replications of measurements is required to estimate representative mean fluxes of a plot or site with a defined level of uncertainty [47], which also depends on the gas species.

\subsection{How to Measure Gas Fluxes?}

During the past decades many studies including the measurements of soil-gas exchange were conducted. Soil gas fluxes were measured in focused individual studies, but also in large monitoring networks (e.g., CarboEurope, Ameriflux, FluxNet, ICOS). The most important field methods used in this context are the micro-meteorological eddy-covariance (EC) method [48] and chamber methods [49]. The gradient-flux method (GM) represents an alternative method $[48,50]$ that is used less often. EC and chamber techniques can only be used to study net fluxes between soil and atmosphere. Applying the GM provides additional insights into ongoing processes in the soil that do not necessarily lead to net fluxes at the surface.

The measuring concept of the EC method postulates turbulent gas transport as dominating gas exchange mechanism in the atmosphere [48,51]. In most cases, EC measurements are conducted in the free atmosphere above the plant cover, which can be a few meters in height in the case of grassland or crop, but also higher than $40 \mathrm{~m}$ in case of tall forests, requiring expensive meteorological towers. The application of EC is restricted to situations and locations with sufficient turbulence. Thus, measurements focusing on soil gas fluxes can be challenging within forest stands due to reduced wind speed and turbulence below the canopy. The application of the EC method requires high frequency measurements of 3D air flow (usually by sonic anemometers) and precise gas concentration measurements (usually by laser gas analysers). Twenty years ago, there were only instruments that could measure $\mathrm{H}_{2} \mathrm{O}$ and $\mathrm{CO}_{2}$ at the required precision and frequency. During the last years, also instruments for $\mathrm{CH}_{4}$ and $\mathrm{N}_{2} \mathrm{O}$ measurements have become available, but are still very expensive. The quality of the EC data is very high and includes the gas exchange of the entire ecosystem, i.e., soil, plants and animals within the footprint which is always depending on the wind direction. The costs and demand for infrastructure per site (devices, tower, power, and maintenance) is substantial.

Chamber measurements represent probably the oldest and most intuitive method to measure soil-atmosphere gas exchange [52]. Different approaches have been used and many issues about the best methodology have been discussed $[47,53]$. The most common application nowadays is the non-steady-state approach [54], which is basically a temporarily closed chamber that covers an area of soil surface so that the gas flux can be derived from the temporal changes in gas concentration within the closed chamber. One prerequisite of this method is that the measurement itself does not interfere with the gas fluxes, or, that this effect is negligible or taken into account in the flux calculation approach. Research showed that there are many pitfalls in the practical application, and that differences in the fluxes estimation of different state of the art chamber systems can be surprising $[55,56]$. Manual chamber measurements are laborious, but their easy application allows covering the study area before permanent sampling locations are fixed. Modifying the setting, chamber measurements can also be used to quantify gas fluxes from different sources, e.g., by using transparent and opaque chambers to separate soil and plant respiration and photosynthesis. In combination with treatments like trenching or girdling of trees chamber measurements can be used to separate soil $\mathrm{CO}_{2}$ fluxes and assign different sources of soil respiration [57]. Practical experience shows that small variations in the manual operation of the chambers may lead to substantial differences, so that a retrospective evaluation of the measurement quality is challenging. Automatic chambers can provide high quality data at high temporal resolution. Yet, they are expensive and require good maintenance and power supply. Additionally, the permanent use of the same measurement position might lead to exclusion of rain which would lead to biased measurements $[47,58]$.

The gradient-flux method or gradient method represents an alternative for measurements of soil-atmosphere fluxes. Assuming gas diffusion as the dominant transport mechanism, the flux of gas in the soil can be calculated based on the soil profiles of gas concentrations and soil gas diffusivity $[44,50]$. While chamber methods measure the soil-atmosphere flux of gas more or less directly, the GM is based 
on a "passive observation" of the driving gradient in the soil gas concentration and the respective exchange coefficient. The GM approach is similar to the approaches used for modelling matrix flow of water in soils. Here, gradients in the soil water potential are the drivers behind the flow of water through the soil pore matrix [59]. The exchange coefficient here is called hydraulic conductivity, and is strongly dependent on the pore structure of the water saturated pores. The exchange coefficient for gas in soil is called soil gas diffusion coefficient, $D_{\mathrm{S}},\left(\mathrm{m}^{2} \mathrm{~s}^{-1}\right)$ and is strongly depended on the pore structure of the air-filled pores and the gas species. The GM allows calculating the gas flux across the soil surface, but it can also provide additional valuable information about the depth profile of sources and sinks of gases $[11,16,60]$. As with chamber measurements, the GM can be used for different gases as long as the soil gas profiles can be measured, i.e., the gas concentrations are within the detection range of the measuring instruments, and the specific $D_{\mathrm{S}}$ of the respective gas species is considered. Most studies focused on $\mathrm{CO}_{2}$ [50,60-65], but there are also many studies that investigated $\mathrm{CH}_{4}$ and $\mathrm{N}_{2} \mathrm{O}$ and other gases $[16,66,67]$ including the isotopic composition of soil gases $[22,68]$.

\subsection{The Gradient-Flux Method: Set-Ups, Approaches, Uncertainties}

While the physical background of the gradient method is accurate and valid, the actual application requires common simplifications from practical gas sampling and gas analysis, necessary assumptions (homogeneous production of gases, soil structure and moisture) to dealing with limited data (measurements). A careful consideration of the simplifications made and the assumptions met can help to assess the sources of uncertainty of the estimated flux value.

Different methodologies have been developed over the decades to sample soil gas. From simple manual sampling using syringes with needles that are inserted into ground to sophisticated sampling devices that allow online monitoring of soil gas concentrations [44]. The first can be used quick and easily. But they do not allow for repeated sampling at the same location, since they disturb the soil structure. Monitoring purposes usually require a permanent installation of a soil gas sampler. Different designs have been developed and optimized to measure repeatedly at certain locations in the soil. The set-ups include simple, thin open-end metal or plastic tubes that are inserted to a specific depth. They require active sampling of air by sucking the air through the access tubes. Yet, it can be difficult to assign a precise depth to the sample if it is drawn under moist conditions and low air-filled pore volume around the sampling location. For accurate assignment of sampling location passive sampling systems are recommended $[16,69,70]$. Passive sampling means that the air is not aspirated into a vial or inlet, but it allows the air within the sampler to equilibrate with the surrounding soil air [70]. This can be achieved by using a silicon tube [71], highly gas permeable tubes [70], or multi-level samplers [69,72].

Measurements of soil gas profiles have followed different paths during recent years. Sampling of soil air and subsequent analysis of the gas vials in the laboratory using gas chromatography (GC) represents the traditional way for precise gas analysis. The development of small solid-state $\mathrm{CO}_{2}$ sensors has greatly simplified and facilitated $\mathrm{CO}_{2}$ concentration measurements, so that these sensors can be easily installed into the soil to monitor soil $\mathrm{CO}_{2}$ concentrations online $[9,64,65,73,74]$. These sensors are inexpensive and easy to handle and allow a very simple set-up (no extra sampler required), yet their application is limited to $\mathrm{CO}_{2}$. The development of highly sensitive laser spectrometers and other technologies for field measurements has facilitated online measurements of additional gases such as $\mathrm{N}_{2} \mathrm{O}$ and $\mathrm{CH}_{4}$, including their isotopic composition [11,70,75]. Such devices and set-ups usually allow a high precision of the measurements, but their demand for resources is quite high (power, costs, sensitive to harsh environments), and they usually measure only one or two gas species. Traditional GC is still an important technology because it allows analysing very small gas volumes at a high precision for up to several gases at a time. The combination of GC analysis and passive samplers facilitates suitable designs for monitoring purposes, because electrical power is not needed at the monitoring sites for the samplers, and samples from several sites can be analysed by one GC system. 
Different approaches for the calculation of the soil gas fluxes have been proposed, from direct simple calculations to analytical and numerical solutions [44]. It is important to consider the implicit assumptions of each calculation approach, since flux estimation can be sensitive to the different calculation procedures [76]. The estimation of soil gas diffusivity has a direct effect on the flux estimation and is, thus, another relevant source of uncertainty. Different models have been developed that allow deriving soil gas diffusivity from soil physical parameters and soil moisture measurements. However, knowing a priori the best suited model for a soil is impossible. Hence, it is recommended to test and validate the assumptions made regarding the diffusivity model used, e.g., by taking soil core samples and measure diffusivity values in the laboratory, or including individual chamber measurements as reference values $[16,74,77]$. Several studies compared flux estimates measured by chambers and GM [44]. Good agreement was found in studies of $\mathrm{CO}_{2}$ production and $\mathrm{CH}_{4}$ consumption in soils. Estimation of soil-atmosphere fluxes of $\mathrm{N}_{2} \mathrm{O}$ have to be considered carefully, since production and consumption of $\mathrm{N}_{2} \mathrm{O}$ can occur on very small scales, and even in the top humus layer, where the soil-atmosphere estimates of the GM are less sensitive [16].

\subsection{Soil Gas Monitoring at the Forest Research Institute Baden Wuerttemberg (FVA-BW)}

The Department of Soil and Environment at FVA-BW established a soil gas monitoring program at the end of the 1990s, which was developed further and maintained since then. The soil gas monitoring program was integrated into the infrastructure and routines at 13 monitoring plots at 6 different sites. These plots are managed and instrumented as Level 2 sites of the intensive environmental monitoring program of the International Co-operative Programme on Assessment and Monitoring of Air Pollution Effects on Forests (ICP Forests), which usually doesn't include any gas measurements. Unlike other large gas flux monitoring networks, the monitoring set-up to study soil gases and soil-atmosphere gas fluxes at FVA-BW is based on a permanent GM installation instead of conventional chamber systems or EC measurements.

In this paper, we present the design and routine of our soil gas monitoring program and discuss its limitations and opportunities. As an illustrative example we will focus on selected data from one site, for which we will present typical patterns of different soil gases and their fluxes, from the long-term perspective to typical seasonal cycles. We will also discuss the methodological uncertainty in the flux calculation using different approaches, and possible applications and research questions that can be addressed with our design and dataset in the future.

\section{Materials and Methods}

\subsection{Soil Gas Monitoring}

\subsubsection{Gas Sampling}

To monitor soil gas concentration, we used arrays of passive gas samplers which are similar to the sampler of Schack-Kirchner et al. [78]. The gas samplers consist of a pipe made of polyvinyl chloride (PVC) which is closed at the lower end, a perforated stainless-steel pipe that leaves the bottom of the PVC pipe in an angle of $90^{\circ}$ and a fine cannula at the bottom inside the PVC pipe (Figure 1, right). Gas vials can be introduced into the PVC pipe from the top and mounted onto the cannula which pierces the septum. The air inside the vial and the soil air around the perforated stainless-steel pipe equilibrate with time. A PVC cap is used to close the top of the sampler.

Small shallow trenches (10-20 cm deep) were carefully dug to install the soil gas samplers. The stainless-steel sampling pipe were then be gently inserted into the undisturbed wall of the trench at the requested depth. The trenches were then filled up again restoring the layering of the soil. The collection of soil air samples always started at least six months after installation, so that the roots could grow back and installation artefacts were minimized. This kind of installation and gas samplings allows a very accurate localization of the depth of the soil gas sampling. Several soil 
gas samplers per depth were installed at $10 \mathrm{~cm}, 5 \mathrm{~cm}$, and $0 \mathrm{~cm}$ depth, to have a sufficient number of replications, with $0 \mathrm{~cm}$ being the interface between mineral soil horizon and the organic layer. Depending on the thickness of the organic layer further samplers were installed at 3 to $2 \mathrm{~cm}$ above $0 \mathrm{~cm}$ depth. Additionally, two modified samplers allowed taking gas samples of the local atmosphere at $5-10 \mathrm{~cm}$ above the soil surface. The gas samplers were attached to a solid rectangular aluminum frame ( 3 by $4 \mathrm{~m}$ ) that was firmly anchored in the ground. Our design included five replicates per depth to allow the quantification of the uncertainty in the estimation of the soil gas concentration gradient.

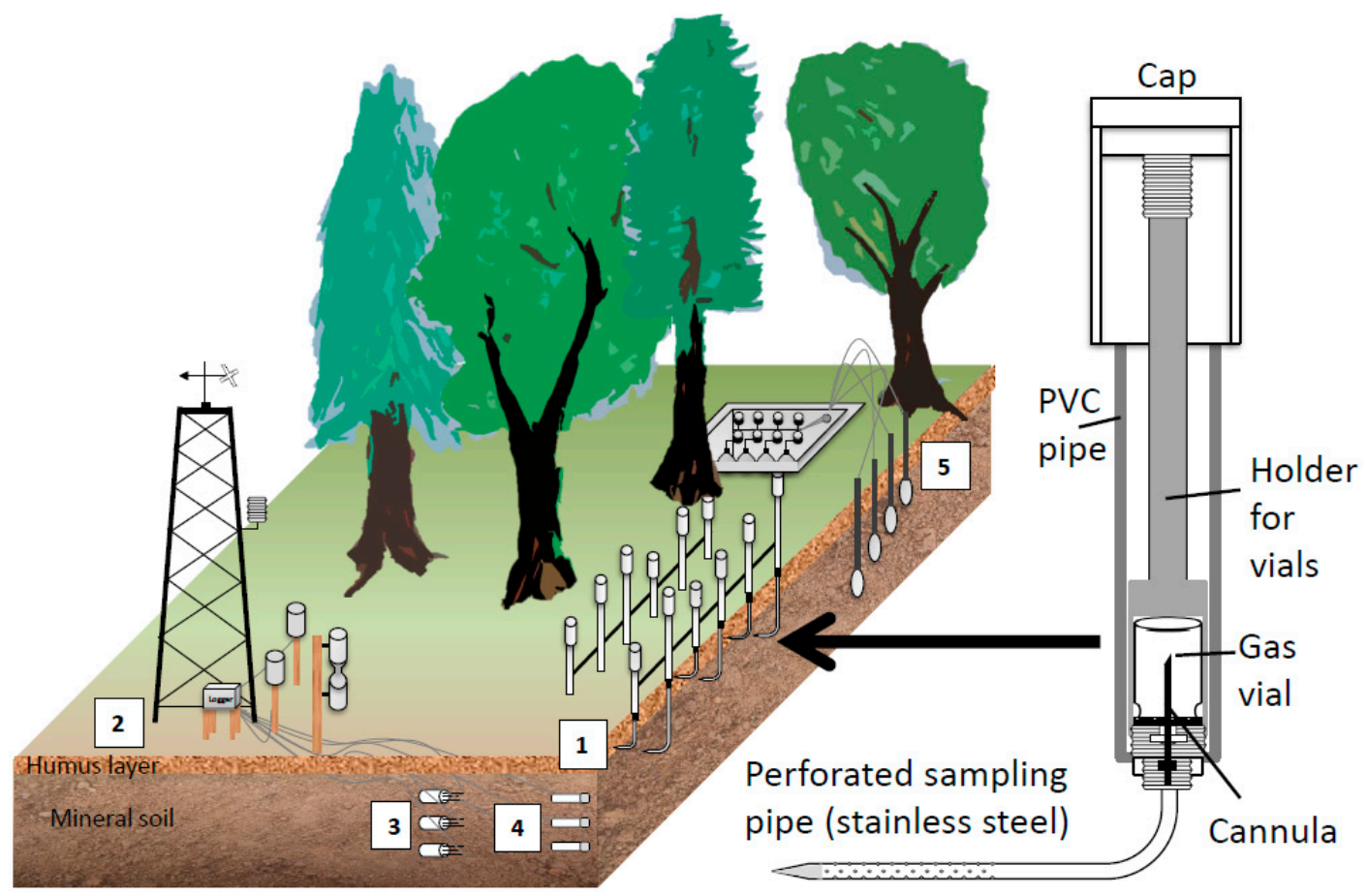

Figure 1. Set-up and instrumentation at the soil gas monitoring sites in Baden-Württemberg. Right: Enlarged view: cross section of a passive gas sampler used for the routine monitoring of soil gas concentrations. Left: The standard set-up included (1) arrays of passive soil gas samplers at different depths (2) a meteorological tower for reference measurements of temperature and precipitation above the canopy, (3) soil moisture sensors, (4) matrix potential and soil temperature sensors, (5) suction cups for collecting soil water.

Before the gas vials were installed in the gas sampler in the field, they were filled with helium (He, ambient pressure) in the laboratory. The gas vials remained in the sampler until the next sampling date. Diffusive exchange and equilibration via the cannula and perforated sampling pipe requires some hours [78]. Thus, the sampled gas in the vial represented an average concentration of the last day. Measuring all gas species with concentrations greater than $0.5 \%\left(\mathrm{~N}_{2}\right.$, $\operatorname{argon}(\mathrm{Ar}), \mathrm{O}_{2}$, and possibly $\left.\mathrm{CO}_{2}\right)$ allowed for checking if the equilibration between vial and soil gas was accomplished. When soils were very wet, all soil pores were possibly saturated with water, and soil gas did not equilibrate with the gas volume in the sampling vial. In such a case a substantial quantity of He remained in the gas vial and the sum of $\mathrm{N}_{2}, \mathrm{Ar}, \mathrm{O}_{2}$, and $\mathrm{CO}_{2}$ was less than $90 \%$. Such data were flagged, and data with less than $60 \%$ exchange were excluded.

\subsubsection{Gas Analysis}

Vials were stored in a fridge until they were analysed, usually within $24 \mathrm{~h}$. Gas samples were analysed using gas chromatography. The gas chromatographs used have been especially configured to meet our specific requirements, using different combinations of columns and detectors to yield 
the best possible separation and detection of the specific gases. Over the last 25 years different gas chromatography systems have been used, but their general set-up remained the same even when the brand or product was updated. Here we report on the set-up that was used during the last five years (Table 1).

Table 1. Set-up and analytical performance of the GC systems used. Relative precision of measurement is given at ambient concentration unless stated otherwise.

\begin{tabular}{|c|c|c|c|c|c|c|c|}
\hline Gas & GC & Column & Detector & $\begin{array}{c}\text { Limit of } \\
\text { Detection }\end{array}$ & Precision & $\begin{array}{l}\text { Atmospheric } \\
\text { Concentration }\end{array}$ & $\begin{array}{l}\text { Typical Soil } \\
\text { Air * }\end{array}$ \\
\hline $\mathrm{CO}_{2}$ & \multirow{6}{*}{$\begin{array}{l}\text { Perkin Elmer } \\
\text { Clarus } 680 \text { GC }\end{array}$} & CP-PoraBond Q & \multirow{4}{*}{ TCD } & $30 \mathrm{ppm}$ & $1.0 \%$ & ca. 400 ppm & $\begin{array}{l}500-20,000 \\
\text { ppm }\end{array}$ \\
\hline $\mathrm{O}_{2}$ & & & & $0.5 \%$ & $0.6 \%$ & $20.95 \%$ & $0-20.95 \%$ \\
\hline $\mathrm{N}_{2}$ & & CP-Molsieve 5A & & $1.7 \%$ & $0.6 \%$ & $78.08 \%$ & ca. $78.08 \%$ \\
\hline $\mathrm{Ar}$ & & & & $0.02 \%$ & $0.8 \%$ & $0.93 \%$ & ca. $0.93 \%$ \\
\hline $\mathrm{CH}_{4}$ & & \multirow{2}{*}{ CP-SilicaPlot } & \multirow{2}{*}{ FID } & $0.27 \mathrm{ppm}$ & $1.6 \%$ & $1.95 \mathrm{ppm}$ & $\begin{aligned} & <0.3 \text { to } \\
> & 100 \mathrm{ppm}\end{aligned}$ \\
\hline $\mathrm{C}_{2} \mathrm{H}_{4}$ & & & & $0.04 \mathrm{ppm}$ & $\begin{array}{l}2.3 \% \text { at } \\
0.5 \mathrm{ppm}\end{array}$ & $0 \mathrm{ppm}$ & 0 to $>5 \mathrm{ppm}$ \\
\hline $\mathrm{N}_{2} \mathrm{O}$ & $\begin{array}{l}\text { Varian CP } \\
3800\end{array}$ & CP-PoraBond Q & ECD & $0.02 \mathrm{ppm}$ & $1.1 \%$ & 0.33 ppm & $<0.2-10 \mathrm{ppm}$ \\
\hline
\end{tabular}

* Typical soil air concentrations from our monitoring plots.

We used two different GC systems that had an auto-sampler each. We used a Clarus 680 GC of Perkin Elmer (Waltham, MA, USA), which included 2 lines of gas chromatography that were supplied by the same autosampler. The first line included a CP-PoraBond Q precloumn $(25 \mathrm{~m}, 0.53 \mathrm{~mm}$ inner diameter (ID), $10 \mu \mathrm{m}$ film) to eliminate air moisture. A CP-Molsieve 5A separation column ( $25 \mathrm{~m} 0.53 \mathrm{~mm}$ ID, $50 \mu \mathrm{m}$ film) and a thermal conductivity detector (TCD) were used to detect $\mathrm{O}_{2}$, $\mathrm{Ar}$, and $\mathrm{N}_{2}$. A parallel CP-PoraBond Q, $(30 \mathrm{~m}, 0.53 \mathrm{~mm}$ ID, $6 \mu \mathrm{m}$ film) after the precolumn allowed separation and detection of $\mathrm{CO}_{2}$, with the same TCD. The same Clarus $680 \mathrm{GC}$ had a second gas chromatography system which included a CP-SilicaPlot column ( $30 \mathrm{~m}, 0.53 \mathrm{~mm}$ ID, $6 \mu \mathrm{m}$ film) and a flame ionization detector (FID) to separate and detect $\mathrm{CH}_{4}$ and $\mathrm{C}_{2} \mathrm{H}_{4}$. Carrier gas was He. As second GC System, we used a Varian CP 3800 gas chromatograph (Varian, Inc., Palo Alto, CA, USA) with a CP-CarboWax 52 CB precolumn ( $25 \mathrm{~m}, 0.53 \mathrm{~mm}$ ID, $2 \mu \mathrm{m}$ film) and CP-PoraBond Q separation column $\left(25 \mathrm{~m}, 0.53 \mathrm{~mm}\right.$ ID, $10 \mu \mathrm{m}$ film and an electron capture detector (ECD) to separate and detect $\mathrm{N}_{2} \mathrm{O}$ at very low concentrations. Carrier gas was a mixture of $\mathrm{Ar}$ and $\mathrm{CH}_{4}$.

Tests showed that the detectors were highly linear within the normal range of soil gas concentrations so that we could run one-point calibration for the daily routine measurements. The precision of the concentration measurements (relative standard deviation $\%$ at atmospheric concentrations and calibration gas) was better than $1.5 \%$ for all gas species but $\mathrm{C}_{2} \mathrm{H}_{4}$ and $\mathrm{CH}_{4}$ (Table 1). This is of special importance because $\mathrm{C}_{2} \mathrm{H}_{4}$ and $\mathrm{CH}_{4}$ concentrations in soil air can be very low and fall below the limit of detection (LOD) and quantification (LOQ estimated as 10/3 $\times$ LOD) of our systems, so that such data have to be treated accordingly. LOD was derived from repeated measurement of sub-ambient concentrations (1:4 and 1:10 dilution of calibration gas with Helium). Atmospheric $\mathrm{C}_{2} \mathrm{H}_{4}$ concentrations are usually below LOD, and in soils only detectable in special situations.

\subsection{Calculating Fluxes Using the Gradient Flux Method}

\subsubsection{Theoretical Background}

Soil gas monitoring provides data like soil gas concentration that can be interpreted directly, e.g., elevated concentrations of $\mathrm{N}_{2} \mathrm{O}$ or $\mathrm{C}_{2} \mathrm{H}_{4}$ that indicate ongoing denitrification or elevated activity of certain microbes. If soil gas concentrations are linked with their exact sampling position and the transport conditions in the soil, gas flux and gas production can be calculated using the gradient 
method [44,50] (Figure 2). Using the gradient method implies that molecular diffusion is the dominating gas transport process in the soil. This means other gas transport processed like mass flow of air [79] and turbulence induced pressure-pumping $[80,81]$ need to be ruled out. These processes can play temporarily a role in highly porous soils and high wind speed, yet their average contribution is probably small.

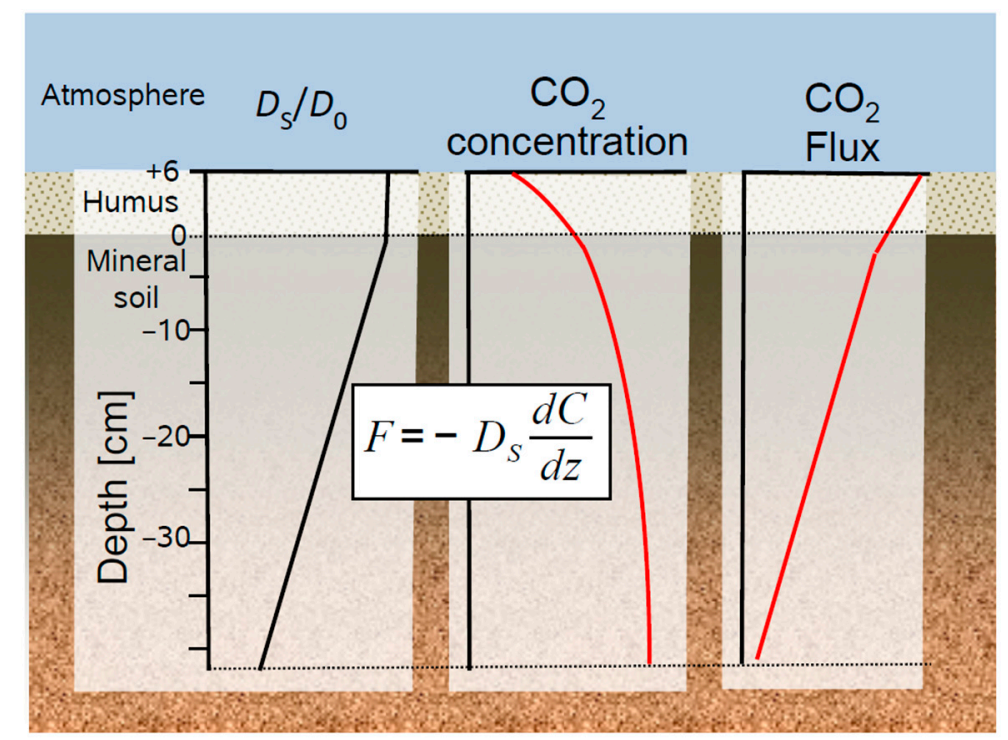

Figure 2. Example of a soil gas profile resulting from soil respiration. Steady-state production and transport of soil $\mathrm{CO}_{2}$ can be described by Fick's first law which links the soil profiles of (left) soil gas diffusivity $\left(D_{\mathrm{S}} / D_{0}\right)$, (middle) $\mathrm{CO}_{2}$ concentration, and (right) the resulting $\mathrm{CO}_{2}$ flux.

Gas diffuses in all directions, which would require a three-dimensional mathematical consideration of gas diffusion in soils [16,22]. In most cases, however, a reduction of the soil profile to a one-dimensional representative simplification is justified and common practices in soil chemistry, soil physics and hydraulic modelling. Hence, gas transport in the soil is often approximated by Fick's first law, which is reduced to its one-dimensional formulation.

$$
F=-D_{\mathrm{S}} \rho_{\text {air }} \frac{\partial \chi_{\mathrm{C}}}{\partial z}
$$

where $F$ is the gas flux $\left(\mathrm{mol} \mathrm{m}{ }^{-2} \mathrm{~s}^{-1}\right)$ at the depth $z(\mathrm{~m}), D_{\mathrm{S}}$ the effective gas diffusion coefficient of the gas species in the soil $\left(\mathrm{m}^{2} \mathrm{~s}^{-1}\right), \rho_{\text {air }}$ the mean air density $\left(\mu \mathrm{mol} \mathrm{m} \mathrm{m}^{-3}\right), \chi_{\mathrm{C}}$ the molar fraction (e.g., atmospheric $\mathrm{CO}_{2}=\chi_{\mathrm{CO}_{2}}=440 \mathrm{ppm}$ or $440 \mu \mathrm{mol} \mathrm{mol}^{-1}$ ) of the diffusing gas species at depth $z$. It is this gradient in molar fraction which drives molecular diffusion, and not the gradient in molar density $\left(\mathrm{C}_{\mathrm{CO}_{2}} ; \mu \mathrm{mol} \mathrm{m}{ }^{-3}\right)[44,82]$. The net production of a gas in soil profile must suffice the conservation of matter, that means:

$$
\frac{\partial C_{\text {sum }}}{\partial t}=-\frac{\partial F}{\partial z}+P
$$

where $C_{\text {sum }}$ is the amount of gas molecules per soil volume $\left(\mu \mathrm{mol} \mathrm{m}{ }^{-3}\right), t$ is time (s), and $P$ the gas production $\left(\mu \mathrm{mol} \mathrm{m} \mathrm{m}^{-3} \mathrm{~s}^{-1}\right)$ Theoretically, $C_{\text {sum }}$ includes the amount of gas in air-filled pores and dissolved in the soil solution, since gas molecules exchange between these compartments. Practically, the dissolution of most trace gases is negligible, if the dissolution of $\mathrm{CO}_{2}$ in a carbonated soil solution is excluded $[65,83]$. 
In most situations and for most gases diffusion can be assumed to be at quasi steady-state [65], so that the change in the amount of gas molecules in a soil volume can be neglected $\left(\partial \mathrm{C}_{\text {sum }} / \partial t=0\right)$. Thus, we can simplify Equation (2) and combine it with Equation (1) so that

$$
P=\frac{\partial}{\partial z}\left(-D_{S} \rho_{a i r} \frac{\partial \chi_{C}}{\partial z}\right) \approx \frac{\partial}{\partial z}\left(-D_{S} \frac{\partial C}{\partial z}\right)
$$

$\rho_{\text {air }}$ may result from strong temperature gradients in the soil, which can be observed as daily cycles in the top soil layer in deserts. In forest soils, however, these gradients in $\rho_{\text {air }}$ can be neglected, and the more common representation of the right side of Equation (3) with $\partial C / \partial z$ can be used $[50,60,74,84]$. The gradient method can be applied for different gases that are measured in a soil profile and which may have different order of magnitudes and even opposite directions. It is important to consider that each flux calculation requires the respective $D_{S}^{i}$ of the diffusing gas $i$.

\subsubsection{Estimation of Soil Gas Diffusion Coefficients}

Soil gas diffusion coefficients are needed to calculate soil gas fluxes from soil gas profiles. $D_{S}^{i}$ represents the exchange coefficient of a specific gas $i$ in the soil and depends on the pore structure of the air-filled pore space $\varepsilon\left(\mathrm{m}^{3} \mathrm{~m}^{-3}\right)$ and the characteristics of the diffusing gas $i$. The relative gas diffusion coefficient $D_{\mathrm{S}} / D_{0}$ is a dimensionless measure of the quality of the structure of soil which allows the quantification of how "easily" a gas is able to diffuse through the pore structure, and which is independent of the gas species. Multiplying this dimensionless coefficient with gas specific diffusion coefficient in free air $D_{0}\left(\mathrm{~m}^{2} \mathrm{~s}^{-1}\right)$ allows calculating the gas specific soil gas coefficient $D_{\mathrm{S}}$ (Equation (4)), which is needed to calculate fluxes.

$$
D_{\mathrm{S}}=\frac{D_{\mathrm{S}}}{D_{0}} D_{0}
$$

$D_{\mathrm{S}} / D_{0}$ depends on the air-filled pore structure, which is often addressed as a combination of the air-filled pore volume and their effectivity to allow gas exchange. Different models have been developed that can be used to calculate $D_{\mathrm{S}} / D_{0}$, from simple general functions [85-88] to functions that require knowledge of many parameters or measurements of diffusivity [89-91]. We used site-specific models since it is impossible to predict the best diffusivity model a priori [44]. The site-specific diffusivity models were derived from laboratory measurements of soil samples from the different sites. Several soil and humus samples were taken at different depths using $100 \mathrm{~cm}^{3}$ soil cores. The porosity of the cores was measured by vacuum pycnometry. Bulk density of samples was measured gravimetrically by drying at $105^{\circ} \mathrm{C}$ after all measurements. Soil gas diffusivity was measured using a one-chamber method similar to the one described by Maier et al. [65]. We used exponential functions as described by Troeh et al. [85] to parameterize our site-specific and soil-layer specific gas diffusivity functions [92]. Using these site-specific gas diffusivity functions allowed calculating the time series of $D_{\mathrm{S}} / D_{0}$ from the air-filled pore-space, which in turn can be calculated as the difference between the total pore-volume and the soil water content. Using Equation (4) allows deriving $D_{S}$ from $D_{S} / D_{0}$. Since the speed of diffusion is affected by temperature $T(\mathrm{~K})$ and barometric pressure $p(\mathrm{~Pa}) D_{0}$ has to be corrected for $T$ and $p$.

$$
D_{0}(T, p)=D_{0}^{\text {norm }}\left(\frac{p_{\text {norm }}}{p}\right)\left(\frac{T}{T_{\text {norm }}}\right)^{\alpha}
$$

where $D_{0}^{\text {norm }}$ is $D_{0}$ at normal barometric pressure $p_{\text {norm }}$ and normal temperature $T_{\text {norm }}$, and $\alpha$ is a gas specific exponent between 1.5 and 2 [93]. Including Equation (5) in Equation (4) allows accounting for the changing environmental conditions on molecular diffusion.

\subsubsection{Measurements and Modelling of Soil Water Content}

The routine program at our monitoring sites includes in situ measurements of environmental parameters at the plot and reference measurements on top of a tower or at an area nearby without forest. 
These continuous measurements include basic meteorological measurements such as air temperature, relative humidity, barometric pressure, wind speed, and precipitation. Soil moisture is measured as volumetric soil moisture content by ML2 and Ml3 probes (Delta-T Devices, Cambridge, UK) at 15, 30 and $60 \mathrm{~cm}$ depth and as soil matric potential using pF-probes (pF-Meter, EcoTech GmbH, Bonn, Germany, GeoPrecision GmbH, Ettlingen, Germany), which included soil temperature measurements.

We used the process-based, one-dimensional soil-vegetation-atmosphere-transport model LWF-Brook 90 [94] to model the water balance at our sites. LWF-Brook 90 was used to simulate daily evapotranspiration and soil water fluxes, along with soil water contents and soil water potentials within a soil profile. Evapotranspiration was calculated by a modified version of the approach by Shuttleworth and Wallace [95]. Soil-hydraulic properties were parameterized using the expressions of van Genuchten [96] and Mualem [97] The soil profile is represented by multiple layers, and the vertical water movement through these layers is described by the Richards equation [98]. The discretization of the soil profile ranged from $1 \mathrm{~cm}$ in the humus layer and in the upper soil to $20 \mathrm{~cm}$ in the subsoil. The model was parameterized using field measurements and typical parameter values [99-101]. The model was calibrated against time series of daily measurements of soil water content, soil matric potential and canopy throughfall. The modeled soil moisture data were used to calculate soil gas diffusivity profiles for all days including the days of the soil gas sampling.

\subsubsection{Calculation Approaches for Soil Gas Fluxes}

Even though the mathematical-physical description included in the gradient-flux method is valid and accurate, there are uncertainties that come with the practical implementation that need to be considered. They result from uncertainties in laboratory measurements of soil physical properties (total pore volume, diffusivity), in situ measurements and modelling (soil water content, soil gas concentration). In addition, spatial heterogeneity and discrete sampling (in time and space) allows only for grasping a snapshot of the reality.

There are different practical approaches to calculate soil gas fluxes from discrete soil gas profiles [44] that were developed to address different challenges [50,60,64,102]. The calculation approach can substantially affect the calculated efflux and the partitioning within the profile [76] and should be carefully chosen. To test and demonstrate the effect of the calculation approach on gas flux estimations we included four different approaches.

Soil gas fluxes were calculated at defined depths by multiplying the gas concentrations gradients with $D_{S}$ of the respective soil layer (Equation (1)). Soil and humus were split into three layers with constant total pore volumes: humus layer, 0 to $5 \mathrm{~cm}$ depth, and 5 to $10 \mathrm{~cm}$ depth. Total pore volume and soil water content were input data to our site and depth specific diffusivity models to calculate profiles of $D_{\mathrm{S}} / D_{0}$. Including $D_{0}$ allowed deriving the $D_{\mathrm{S}}$ of each gas (Equations (4) and (5)). $D_{0}$ was adjusted to the current temperature and barometric pressure [93], which was derived from a weather station nearby of the German Meteorological Service (DWD) and corrected for differences in altitude when own pressure measurements were lacking. The harmonic mean of the Ds profile between the respective gas sampling depths was calculated as representative average of the respective soil layer [103].

In contrast to many other studies, we had five soil gas samplers per depth at four to five different depths in the soil to obtain a representative gas profile in the humus layer and the top $10 \mathrm{~cm}$ of the mineral soil. If only one concentration measurement per depth is available, as in other studies, the calculation of the concentration gradients in the soil is a simple approach of discrete differences $[50,64]$. With several measurements per depth different regression approaches can be used $[44,76]$. The same $D_{S} / D_{0}$ data were used for all flux calculation approaches. The first approach is based on local linear regressions (LL) that is done for all soil layers separately [76], i.e., all concentration measurements from 10 to $5 \mathrm{~cm}$ depth were used to calculate a representative concentration gradient for the respective layer using a simple linear regression function. The same was done for the -5 to $0 \mathrm{~cm}$ layer, and then the humus layer. The second approach is a linear regression (LR) across the entire soil gas profile for which all concentration measurement from the atmosphere to $10 \mathrm{~cm}$ depth were used to 
calculate one average concentration gradient for the entire profile [64]. As third approach, we used a linear spline function (LS) with a node at the soil-humus interface $(0 \mathrm{~cm}$ depth) and at $5 \mathrm{~cm}$ depth in the mineral soil. The derived fluxes of the LL and LS approach were assigned to the middle of the respective layers. The fourth approach fits an exponential function (EF) for the entire concentration profile [60]. The soil-atmosphere flux of $\mathrm{CO}_{2}$ and $\mathrm{CH}_{4}$ was calculated using all four approaches to compare the different calculation approaches. Since the LL and LS calculation approaches are not able to estimate the concentration gradient at the soil-atmosphere interface directly, the flux estimations in the humus layer and in the 10 to $5 \mathrm{~cm}$ depth layer were used to extrapolate the flux to the surface [104]. The LR approach only yields one concentration gradient for the entire profile, so it could not be extrapolated. For EF the gradient at the atmosphere-humus interface was used.

For the detailed interpretation of typical patterns of soil gas fluxes we present LL derived flux estimates, unless it is stated otherwise. The LR approach was used to calculate $\mathrm{O}_{2}$ fluxes since the lower relative measurement precision of $\mathrm{O}_{2}$ concentrations required an approach that was less sensitive to possible outliers. It is generally assumed that the organic layer hardly contributes to $\mathrm{CH}_{4}$ consumption [105]. Thus, negative soil $\mathrm{CH}_{4}$ fluxes $\left(\mathrm{CH}_{4}\right.$ consumption) were not extrapolated to the soil surface but calculated directly from the observed $\mathrm{CH}_{4}$ gradient in the humus layer. We considered the uncertainty of the estimation of the diffusivity and of the concentration gradient to quantify the uncertainty included in the soil-atmosphere fluxes. Uncertainty of the diffusivity estimation results from the uncertainty soil water content measurement which was set to $+/-2$ Vol. $\%$, and the diffusivity model, which was not considered here. Uncertainty of the gradient estimation was calculated from the regression function for $\mathrm{CH}_{4}$ and $\mathrm{O}_{2}$, and based on the propagation of errors of the flux estimates for the extrapolated soil-atmosphere flux for $\mathrm{CO}_{2}$. The statistical programming language $\mathrm{R}$, Version 4.0.2 (22 June 2020) [106] was used for data processing unless stated otherwise, including the packages ggplot2 [107] and dplyr [108].

\subsection{Monitoring Sites}

FVA-BW manages and maintains 13 monitoring plots at 6 different sites (Figure 3, Tables 2 and 3) Rotenfels (RO) Altensteig (AL), Conventwald (CO), Heidelberg (HD), Ochsenhausen (OC)) in the forests of Baden-Württemberg, Germany. Of these 13 plots, ten plots at 5 sites are also listed as ICP Level 2 Monitoring plots according the ICP Forest Intensive Monitoring Program [109].

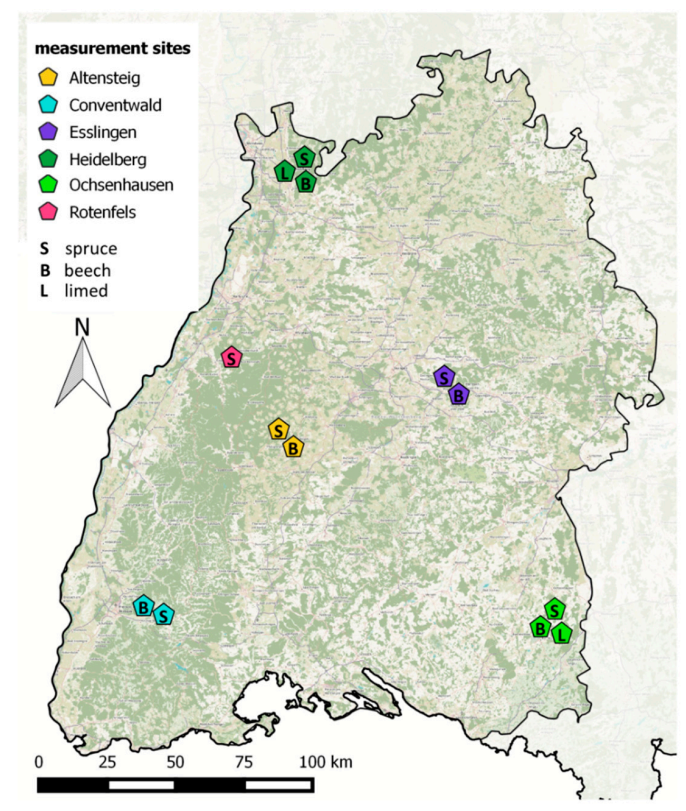

Figure 3. Map of Baden Württemberg (SW Germany) showing the sites with soil gas monitoring run by Forest Research Institute Baden Wuerttemberg (FVA-BW). Dark green indicates forest areas. 
Each site has a plot of Beech forest (Fagus sylvatica. L.) and a plot of Spruce forest (Picea abies. (L) H. Karst.). The sites Heidelberg and Ochsenhausen include an additional treatment plot where the soil has been limed with $\mathrm{CaMg}\left(\mathrm{CO}_{3}\right)_{2}$ in 1984 and 1994, respectively. An additional Spruce plot was installed in Rotenfels, which is not part of the regular ICP Level 2 monitoring program. The sites and plots were selected to represent the typical forest regions of Baden-Württemberg and the most frequent local broadleaved tree (beech) and conifer species (spruce). All plots have been established before 1995 and are managed according to the guidelines for the ICP Level 2 monitoring program Soil gas monitoring started in 1998 on 8 plots and 2010 on 5 plots.

Table 2. Monitoring sites including soil gas monitoring managed by FVA-BW. Data represent annual average values.

\begin{tabular}{cccccccc}
\hline Site & Acronym & Plot & Latitude & Longitude & $\begin{array}{c}\text { Altitude } \\
(\mathbf{m})\end{array}$ & $\begin{array}{c}\text { Precipitation } \\
(\mathbf{m m})\end{array}$ & $\begin{array}{c}\text { Temperature } \\
\left({ }^{\circ} \mathbf{C}\right)\end{array}$ \\
\hline Rotenfels & RO & 1 & $48.82^{\circ}$ & $8.40^{\circ}$ & 600 & 1258 & 9.0 \\
Altensteig & AL & 2 & $48.59^{\circ}$ & $8.63^{\circ}$ & 512 & 821 & 8.5 \\
Conventwald & CO & 2 & $48.02^{\circ}$ & $7.97^{\circ}$ & 810 & 1385 & 8.3 \\
Esslingen & ES & 2 & $48.76^{\circ}$ & $9.43^{\circ}$ & 348 & 781 & 9.6 \\
Heidelberg & HD & 3 & $49.45^{\circ}$ & $8.75^{\circ}$ & 510 & 1113 & 7.4 \\
Ochsenhausen & OC & 3 & $48.01^{\circ}$ & $9.96^{\circ}$ & 680 & 1111 & 8.6 \\
\hline
\end{tabular}

The plots are covered by homogenous forests stand of approximately 0.25 ha (Table 3 ). The spruce plot and the beech plot are located next to each other. The management routine includes a combination of in situ measurements by permanently installed sensors and data loggers and repeated sampling (automatic and manual) on a regular scheme and subsequent analysis in the laboratory. Infrastructure and routines for soil gas monitoring have been established in addition to the internationally harmonized monitoring routine of the ICP Forest monitoring network. For the presentation of exemplary results we used data of the spruce plot of the ES site from the years 2005-2020.

Table 3. Description of the forest stands and soils at the monitoring plots. Soil types were classified using the World Reference Base for Soil resources [110].

\begin{tabular}{|c|c|c|c|c|c|c|c|c|}
\hline \multicolumn{3}{|c|}{ Forest Stand } & \multicolumn{4}{|c|}{ Soil } & \multicolumn{2}{|c|}{ Humus } \\
\hline Plot & Age & Height (m) & Type & $\mathrm{pH}$ & Texture & Coarse Soil (\%) & Type & Depth (cm) \\
\hline RO spruce & 128 & 37.2 & $\begin{array}{c}\text { Hyperalbic } \\
\text { Podzol }\end{array}$ & 2.94 & Su3 & 25 & $\begin{array}{l}\text { Rawhumus } \\
\text { (ROR) }\end{array}$ & 15 \\
\hline AL spruce & 110 & 37.1 & $\begin{array}{l}\text { Haplic } \\
\text { Cambisol }\end{array}$ & 3.26 & $\mathrm{Sl} 3$ & 5 & Mull (MUO) & 8 \\
\hline AL beech & 138 & 28 & $\begin{array}{l}\text { Stagnic } \\
\text { Cambisol }\end{array}$ & 3.77 & $\mathrm{Sl} 3$ & 1 & Mull (MUO) & 6 \\
\hline CO spruce & 98 & 34 & $\begin{array}{l}\text { Haplic } \\
\text { Cambisol }\end{array}$ & 3.43 & $\mathrm{Sl} 4$ & 80 & $\begin{array}{l}\text { Moder } \\
(\mathrm{MOT})\end{array}$ & 10 \\
\hline $\mathrm{CO}$ beech & 138 & 31.5 & $\begin{array}{l}\text { Skeletic } \\
\text { Cambisol }\end{array}$ & 3.1 & Ls2 & 50 & $\begin{array}{l}\text { Moder } \\
\text { (MOT) }\end{array}$ & 3 \\
\hline ES spruce & 110 & 41.9 & $\begin{array}{c}\text { Vertic } \\
\text { Stagnosol }\end{array}$ & 3.24 & Ls2 & 0 & $\begin{array}{l}\text { Moder } \\
(\mathrm{MOT})\end{array}$ & 6 \\
\hline ES beech & 138 & 33.2 & $\begin{array}{l}\text { Haplic } \\
\text { Stagnosol }\end{array}$ & 3.61 & $\mathrm{~S} 14$ & 2 & Mull (MUF) & 4 \\
\hline HD spruce & 108 & 32.3 & $\begin{array}{l}\text { Haplic } \\
\text { Cambisol }\end{array}$ & 2.87 & $\mathrm{Sl} 3$ & 10 & $\begin{array}{l}\text { Moder } \\
\text { (MOT) }\end{array}$ & 7 \\
\hline $\mathrm{HD}^{*}$ spruce & 108 & 32.3 & $\begin{array}{l}\text { Haplic } \\
\text { Cambisol }\end{array}$ & 2.87 & $\mathrm{Sl} 3$ & 10 & $\begin{array}{l}\text { Moder } \\
\text { (MOT) }\end{array}$ & 7 \\
\hline HD beech & 83 & 27.5 & $\begin{array}{l}\text { Haplic } \\
\text { Stagnosol }\end{array}$ & 3.52 & Ls2 & 1 & Mull (MUF) & 3 \\
\hline OC spruce & 100 & 33.6 & $\begin{array}{l}\text { Abruptic } \\
\text { Luvisol }\end{array}$ & 3.15 & $\mathrm{Lu}$ & 2 & $\begin{array}{l}\text { Moder } \\
\text { (MOR) }\end{array}$ & 9 \\
\hline OC ${ }^{*}$ spruce & 100 & 33.6 & $\begin{array}{l}\text { Abruptic } \\
\text { Luvisol }\end{array}$ & 4.1 & $\mathrm{Lu}$ & 8 & $\begin{array}{l}\text { Moder } \\
\text { (MOR) }\end{array}$ & 10 \\
\hline OC beech & 138 & 36.4 & $\begin{array}{l}\text { Epidystric } \\
\text { Luvisol }\end{array}$ & 3.25 & Ut3 & 2 & $\begin{array}{l}\text { Moder } \\
\text { (MOR) }\end{array}$ & 3 \\
\hline
\end{tabular}

* Indicated sites received liming treatments. 


\section{Results and Discussion}

\subsection{Time Series of $\mathrm{O}_{2}, \mathrm{CO}_{2}, \mathrm{CH}_{4}, \mathrm{~N}_{2} \mathrm{O}$ and $\mathrm{C}_{2} \mathrm{H}_{4}$ and Typical Soil Gas Profiles}

\subsubsection{Time Series and Seasons}

We present typical examples and interpretations of selected data from the Spruce monitoring plot at the ES site (Figure 4). All data were quality checked and filtered so that the different gases presented in this example cover different time slots. $\mathrm{N}_{2}$ and Ar are not shown since they were only used for quality assurance purposes.

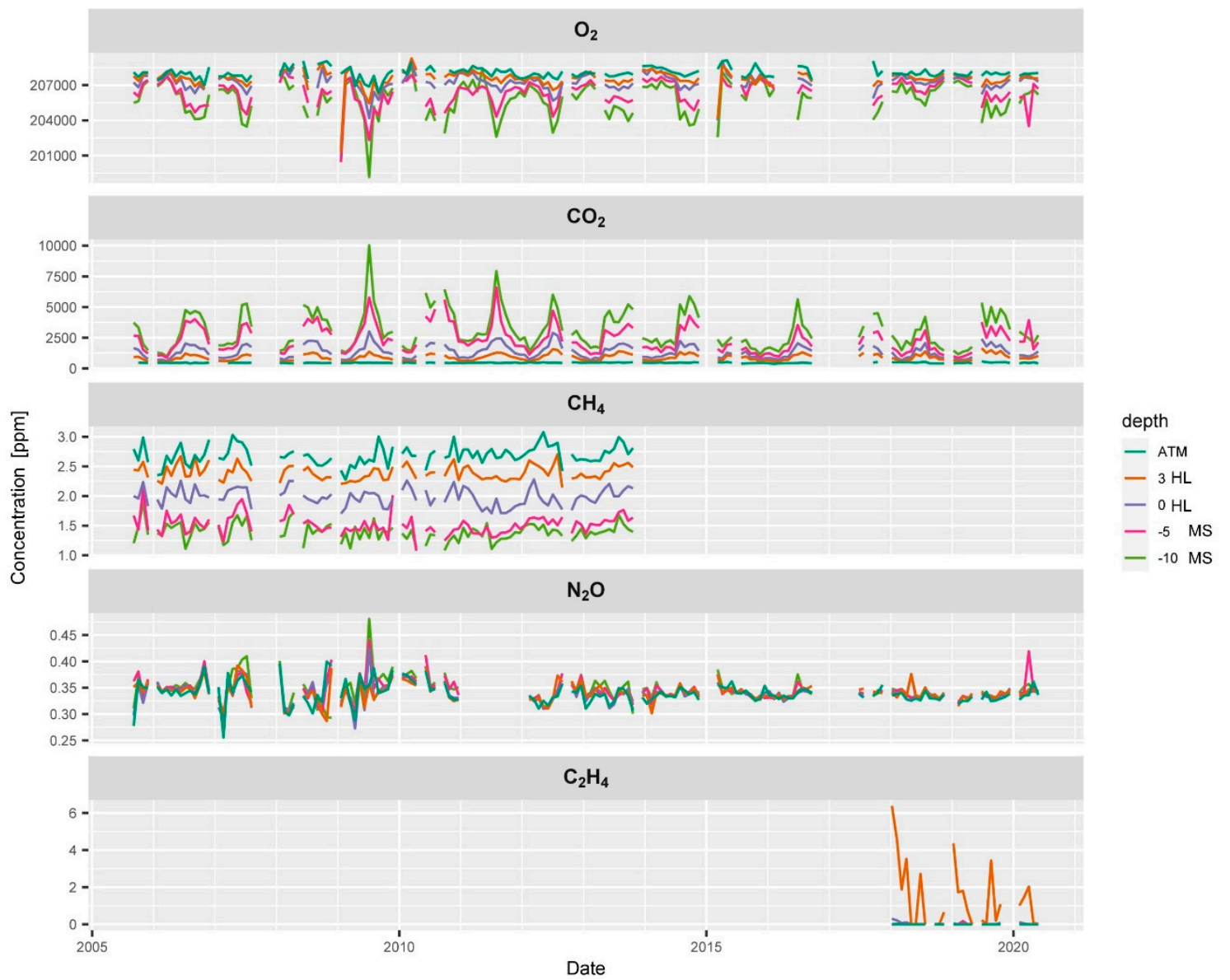

Figure 4. Time series of the soil gas profile at the ES spruce plot showing the course of average concentrations of $\mathrm{O}_{2}, \mathrm{CO}_{2}, \mathrm{CH}_{4}, \mathrm{~N}_{2} \mathrm{O}$ and $\mathrm{C}_{2} \mathrm{H}_{4}$ at different positions in the mineral soil (-10, -5, MS), in the humus layer ( $0,3, \mathrm{HL})$, and in the atmosphere (ATM). $\mathrm{CO}_{2}, \mathrm{O}_{2}$ and $\mathrm{N}_{2} \mathrm{O}$ concentration measurements cover almost the entire observation period, while technical difficulties limit the data availability of $\mathrm{CH}_{4}$ and $\mathrm{C}_{2} \mathrm{H}_{4}$ concentrations.

$\mathrm{O}_{2}$ concentrations always decreased with depth indicating consumption of $\mathrm{O}_{2}$ by the soil (Figure 4). A clear seasonality in $\mathrm{O}_{2}$ concentrations was registered (Figure 5) with $\mathrm{O}_{2}$ concentrations reaching down to 200,000 ppm (20\%), which is approx. 8000 ppm below the atmospheric concentration of $\mathrm{O}_{2}$ (Figure 4). This means, this soil was always well-aerated. Soil $\mathrm{CO}_{2}$ showed an opposite course and clearly increased in concentration with depth throughout the entire time series (Figure 5). $\mathrm{CO}_{2}$ concentrations ranged from $400 \mathrm{ppm}$ near the soil surface to $10,000 \mathrm{ppm}$ in $10 \mathrm{~cm}$ depth. Soil $\mathrm{CO}_{2}$ also shows a typical seasonality with much higher concentrations in the summer when temperatures and soil respiration is highest (Figure 5). 

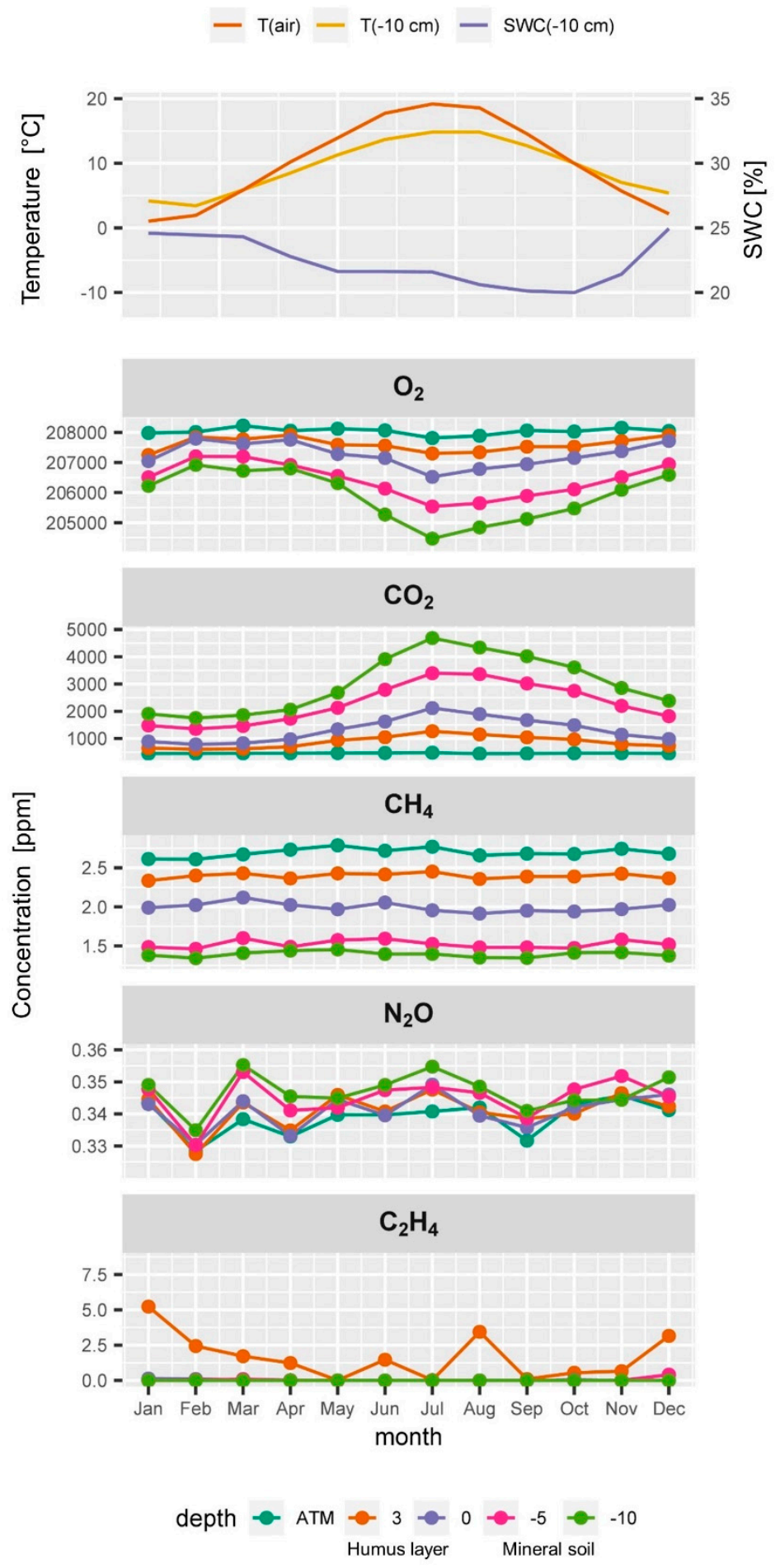

Figure 5. Typical seasonal time course of (from top to bottom) air temperature (T(air)), soil temperature $(\mathrm{T}(-10 \mathrm{~cm}))$ and soil water content $(\mathrm{SWC}(-10 \mathrm{~cm}))$ at $10 \mathrm{~cm}$ depth, and averaged monthly soil gas concentrations of $\mathrm{O}_{2}, \mathrm{CO}_{2}, \mathrm{CH}_{4}, \mathrm{~N}_{2} \mathrm{O}$, and $\mathrm{C}_{2} \mathrm{H}_{4}$ of all samplers at a depth in the soil profile and in the atmosphere (ATM).

Atmospheric $\mathrm{CH}_{4}$ concentrations at the ES spruce plot were higher on average (2.6 pmm) than expected and seemed to fluctuate slightly over time. Soil $\mathrm{CH}_{4}$ concentrations always showed a strong decrease with depth indicating $\mathrm{CH}_{4}$ consumption by methanotrophic bacteria within the soil profile.

Soil $\mathrm{CH}_{4}$ reached concentrations as low as $1 \mathrm{ppm}$ at $10 \mathrm{~cm}$ depth (Figure 4). $\mathrm{CH}_{4}$ concentrations did not show a clear seasonality unlike $\mathrm{CO}_{2}$ and $\mathrm{O}_{2}$ (Figure 5). The relatively high atmospheric $\mathrm{CH}_{4}$ 
concentrations could be due to a strong local $\mathrm{CH}_{4}$ source e.g., an industrial area, a biogas plant or peatland. It could also partly result from the relative uncertainty of the calibration gas and other artefacts. The apparently elevated atmospheric $\mathrm{CH}_{4}$ concentration had only an indirect effect since our monitoring and flux calculation approach rather relies on detecting vertical gradients than measuring the absolute concentration. To find out about or source of $\mathrm{CH}_{4}$ or possible artefact we are currently planning $\mathrm{CH}_{4}$ measurements with an independent gas analysis system. The time series of $\mathrm{N}_{2} \mathrm{O}$ neither showed a clear seasonality nor clear depth gradients. They often showed a very weak increase in concentration with depth, yet the variability at a given depth was often in a similar range (Figure 4). Calculating a seasonal average course from the entire time series (Figure 5) showed that this weak increase with depth was persistent during most of the seasons, which is an indication of an ongoing weak mean denitrification and production of $\mathrm{N}_{2} \mathrm{O}$.

Reliable measurement of soil $\mathrm{C}_{2} \mathrm{H}_{4}$ concentrations (above the detection limit) could be collected only after 2017 at this site (Figure 4). Most values of $\mathrm{C}_{2} \mathrm{H}_{4}$ measurements were below the detection limit which is normal for a well aerated soil. Despite the good supply of $\mathrm{O}_{2}$ we detected concentrations of up to 6 ppm of $\mathrm{C}_{2} \mathrm{H}_{4} . \mathrm{C}_{2} \mathrm{H}_{4}$ concentrations seemed to have higher values in winter (Figure 5) when soil water content was higher and soil gas diffusivity lower. In summer, when soil temperature peaked and soil microbial activity was highest, $\mathrm{C}_{2} \mathrm{H}_{4}$ concentrations also seemed to become temporarily higher. The detected $\mathrm{C}_{2} \mathrm{H}_{4}$ concentrations of up to $6 \mathrm{ppm}$ in the humus layer can be considered as a high value [27].

We think that the production of $\mathrm{C}_{2} \mathrm{H}_{4}$ occurs at hot spots similar to the production of $\mathrm{N}_{2} \mathrm{O}$. This is in contrast to the more or less evenly distributed production $\mathrm{CO}_{2}$ or consumption of $\mathrm{O}_{2}$ which results in more homogenous soil gas profiles. Calculating $\mathrm{C}_{2} \mathrm{H}_{4}$ fluxes or production rates was not feasible due to the limited data and its small-scale processes. Nevertheless, studying the dynamics and spatiotemporal patterns of the $\mathrm{C}_{2} \mathrm{H}_{4}$ data at all 13 monitoring plots promises new insights in intensity and frequency of situations during which $\mathrm{C}_{2} \mathrm{H}_{4}$ is produced in forest soils. The analysis of long term $\mathrm{C}_{2} \mathrm{H}_{4}$ data will allow the identification of drivers and effects, such as drought, liming, enhanced mineralization, waterlogged soils and biotic stressors.

\subsubsection{Typical Soil Gas Profiles}

Soil water content, soil temperature and soil gas diffusivity are important drivers and underlay seasonal cycles (Figures 5 and 6 ). $D_{\mathrm{S}} / D_{0}$ is highest in the humus layer and lower in the deeper mineral soil layers (Figure 6 top). This is an effect of the decrease in total pore space with depth which results from the load of the soil above $[45,65]$. $D_{\mathrm{S}} / D_{0}$ is decreasing with depth within each layer because soil water content is usually increasing with depth. The typical $D_{S} / D_{0}$ profile changes through the seasons. The wet seasons of spring and winter have higher soil water contents and thus lower $D_{\mathcal{S}} / D_{0}$ values than the warmer and drier seasons of summer and fall (Figures 5 and 6).

Soil gas profiles data $\left(\mathrm{O}_{2}, \mathrm{CO}_{2}, \mathrm{CH}_{4}\right.$ and $\left.\mathrm{N}_{2} \mathrm{O}\right)$ were grouped according to their season (Figure 6). Seasonal average values per sampler were calculated instead of monthly averages of all five samplers per depth (as shown in Figure 5) to represent the variability covered by the replications. That means variability of the green dots at a given depth shown in Figure 6 represents the average spring concentration of one specific sampler at a given depth. This allows assessing the homogeneity of the soil gas profiles and gives some information on possibly simultaneously occurring processes 


$$
\text { season — spring — summer — fall — winter }
$$
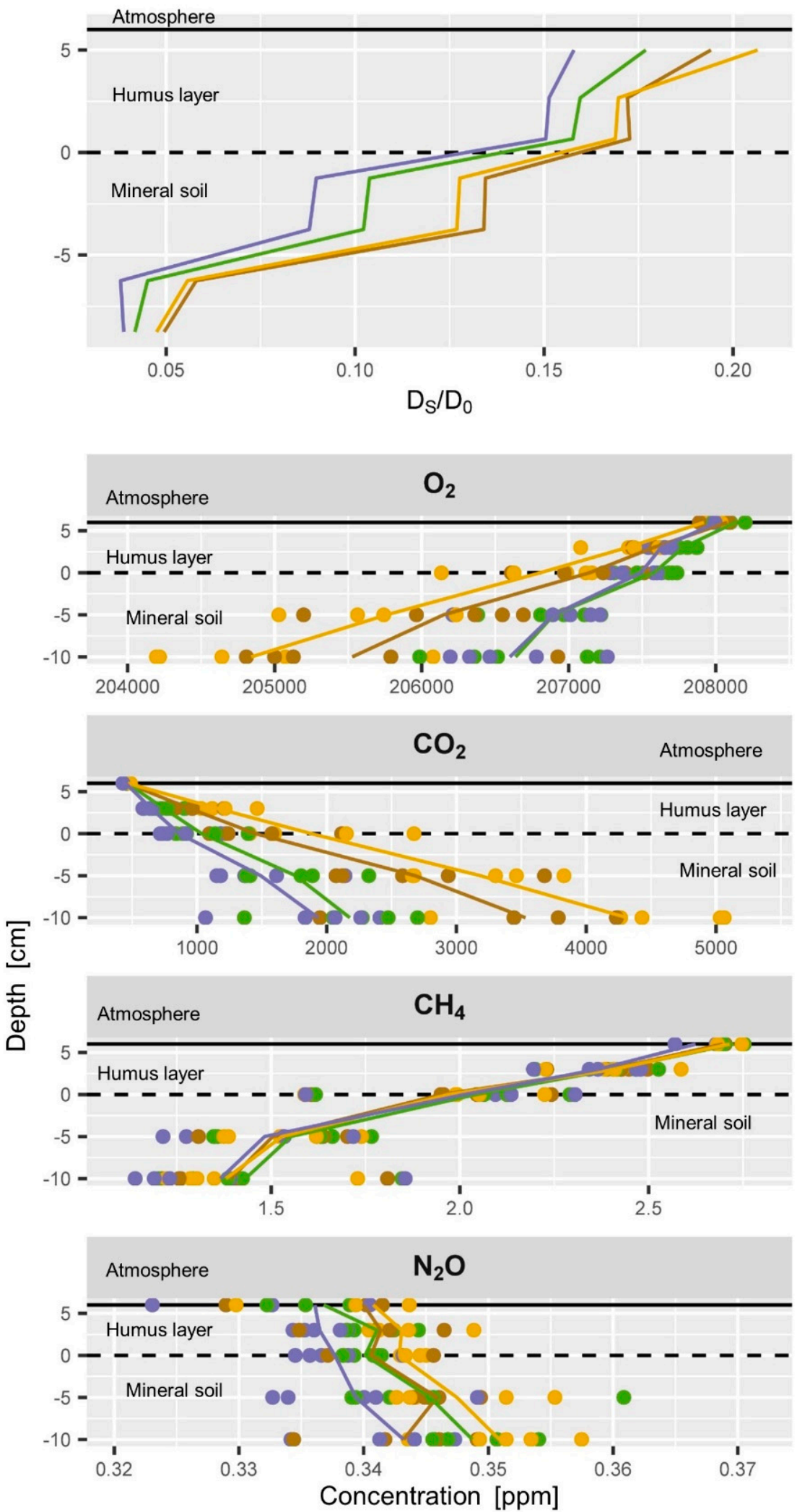

Figure 6. Typical seasonal soil profiles of (top) soil gas diffusivity $\left(D_{\mathrm{S}} / D_{\mathrm{O}}\right)$ and (below) soil gas concentrations of $\mathrm{O}_{2}, \mathrm{CO}_{2}, \mathrm{CH}_{4}$ and $\mathrm{N}_{2} \mathrm{O}$. Seasons are indicated by colours for spring (green), summer (yellow), fall (brown) and winter (blue). Each dot represents the average seasonal value of one sampler. Vertical lines connect average values per depth. 
$\mathrm{O}_{2}$ decreased with depth in all seasons, similar to the increase in $\mathrm{CO}_{2}$ with depth. The $\mathrm{CO}_{2}$ and $\mathrm{O}_{2}$ gradients are much stronger in summer than in winter and spring. Average summer concentrations of $\mathrm{CO}_{2}$ and $\mathrm{O}_{2}$ of all samplers are clearly different from winter concentrations (blue and yellow dots do not mix), because the strong seasonal cycle dominates the variability of each sampler at all depths. The $\mathrm{O}_{2}$ gradient is strongest during summer and lowest $\mathrm{O}_{2}$ values were registered in $10 \mathrm{~cm}$ depth in the summer seasons, as observed in the seasonal time course of soil gas concentrations (Figure 4). Seasonal soil $\mathrm{CO}_{2}$ concentrations were very similar to the $\mathrm{O}_{2}$ profiles but had slightly bigger differences between the winter and spring profiles than the $\mathrm{O}_{2}$ data (Figure 6). The $\mathrm{CO}_{2}$ concentrations of all samplers showed a persistent ranking over time according to their depth, but also at each depth (data not shown). The lower absolute precision of the concentration measurement of $\mathrm{O}_{2}$ compared to $\mathrm{CO}_{2}$ resulted in a slightly larger scattering of daily profiles, which was smoothed out by averaging seasonal $\mathrm{O}_{2}$ profiles in Figures 5 and 6 . Yet, daily $\mathrm{O}_{2}$ profiles included a higher uncertainty in the concentration measurement than $\mathrm{CO}_{2}$ profiles.

The seasonal soil $\mathrm{CH}_{4}$ concentrations showed an almost constant profile all year round with a linear decrease in $\mathrm{CH}_{4}$ concentration from the soil surface to $5 \mathrm{~cm}$ depth (Figures 5 and 6) which means that the gradients did not vary too much over time and within the top soil. One of the five samplers at $10 \mathrm{~cm}$ depth had average $\mathrm{CH}_{4}$ concentrations from 1.7 to $1.8 \mathrm{ppm}$ throughout the seasons while all other samplers always had $\mathrm{CH}_{4}$ concentrations below $1.5 \mathrm{ppm}$. This indicates either (a) a weak local net production of $\mathrm{CH}_{4}$ near this sampler while net consumption of $\mathrm{CH}_{4}$ dominated the rest of the soil gas profile, (b) less $\mathrm{CH}_{4}$ consumption above this sampler, or (c) a locally higher soil gas diffusivity above the sampler. Since also $\mathrm{CO}_{2}$ and $\mathrm{O}_{2}$ concentrations of this gas sampler were closer to atmospheric concentrations, (c) is most probable. $\mathrm{CH}_{4}$ concentrations of all samplers showed a persistent ranking over time as observed for $\mathrm{CO}_{2}$. This persistence of the ranking over time is a clear hint that our sampling and measurements are highly reproducible and that our set-up allows detecting even small changes in the dynamics of soil gases.

Time series of the seasonal $\mathrm{N}_{2} \mathrm{O}$ concentrations at a depth (Figures 4 and 5) and seasonal profiles (Figure 6) showed a high variability in the $\mathrm{N}_{2} \mathrm{O}$ profile and a large overlap of concentrations between the seasons. Averaged monthly atmospheric $\mathrm{N}_{2} \mathrm{O}$ concentrations ranged from 324 to $340 \mathrm{ppb}$ (Figures 5 and 6) which is half the variability as observed within the soil profile (324 to $361 \mathrm{ppb}$ ). Even if an increase of $\mathrm{N}_{2} \mathrm{O}$ concentrations with depth might be apparent from Figures 5 and 6, we have to consider that the variability of $\mathrm{N}_{2} \mathrm{O}$ concentrations at each depth is larger than the profile gradient (Figure 6). The weak increase in $\mathrm{N}_{2} \mathrm{O}$ concentrations in the mineral soil indicates a weak ongoing production of $\mathrm{N}_{2} \mathrm{O}$. Yet, the $\mathrm{N}_{2} \mathrm{O}$ gradient in the humus layer was sometimes negative and sometimes positive, and often weak and not significant. This can result from (a) insufficient precision of the measurement, (b) intrinsic variability of the soil gas profile resulting from small scale processes, or (c) absence of $\mathrm{N}_{2} \mathrm{O}$ production or consumption. Regarding (a) we conclude that the observed average $\mathrm{N}_{2} \mathrm{O}$ profiles of approx. $10 \mathrm{ppb}$ can be reliably detected considering the measurement precision of $\mathrm{N}_{2} \mathrm{O}$ of approximately. $3.6 \mathrm{ppb}$ (Table 1). The even larger variability of 10-20 ppb between the replication samplers at each depth indicates that the lack of statistical significance in of the overall soil $\mathrm{N}_{2} \mathrm{O}$ gradient results from (b) simultaneously occurring small scale production and consumption of $\mathrm{N}_{2} \mathrm{O}$. Forest soils can take up atmospheric $\mathrm{N}_{2} \mathrm{O}$ [19]. This would be in agreement with the sub ambient concentrations [16,42] which were observed in the humus layer from time to time. Measurement of $\mathrm{N}_{2} \mathrm{O}$ uptake is generally very difficult since $\mathrm{N}_{2} \mathrm{O}$ uptake rates are usually very low and often below the detection limit of regular chamber measurements [42,111]. We also observed $\mathrm{N}_{2} \mathrm{O}$ concentrations in the humus layer above atmospheric concentrations from time to time which would indicate a net production of $\mathrm{N}_{2} \mathrm{O} . \mathrm{N}_{2} \mathrm{O}$ concentrations in forest soils can reach up to several ppm [76,112]. Especially in agricultural soils, $\mathrm{N}_{2} \mathrm{O}$ fluxes can be very high after flooding or fertilization [113]. High $\mathrm{N}_{2} \mathrm{O}$ concentrations were also observed from time to time at our other soil gas monitoring plots, especially during periods of enhanced mineralization of the humus layer (data not shown). The observed $\mathrm{N}_{2} \mathrm{O}$ concentration profiles at this plot, however, did not show strong 
gradients and possible emissions or consumption could not be calculated. The $\mathrm{N}_{2} \mathrm{O}$ balance of a forest or agricultural site rather depends on catching the peak events $[113,114]$, than spanning the potentially long time between the peak events when fluxes might be negligible. A regular schedule might thus be a drawback. Covering long time series which combine discrete measurements (soil gas) and continuous measurement (temperature, soil moisture), on the other hand, allows to stochastically estimate the probability of $\mathrm{N}_{2} \mathrm{O}$ peak emissions events and to identify the drivers. This would allow then modelling the undetected peaks using the continuous proxies.

\subsection{Effect of Different Calculation Approaches for Gas Flux Estimation}

\subsubsection{Comparison of Calculation Approaches}

Four different calculation approaches for the estimation of the soil-atmosphere gas flux were compared. For the comparison $\mathrm{CH}_{4}$ and $\mathrm{CO}_{2}$ concentration data were used. Soil respiration estimates of all four approaches yielded similar values, while the effect of the calculation approach was more pronounced for the $\mathrm{CH}_{4}$ consumption estimation (Figure 6, middle, right). The ranking between the different approaches was the same for soil respiration and $\mathrm{CH}_{4}$ consumption: the $\mathrm{LR}$ approach yielded the lowest soil respiration and $\mathrm{CH}_{4}$ consumption estimates followed by $\mathrm{EF}$ approach. Estimates of the LL and LS approach were very similar. While other comparisons [76] found large overestimation by the EF approach, we observed substantially lower flux estimates for the $\mathrm{EF}$, but only for $\mathrm{CH}_{4}$ and not $\mathrm{CO}_{2}$.

We explain the consistency of the different approaches by the linear shape of the $\mathrm{CO}_{2}$ profile in the top soil (Figure 5) that can be appropriately fit and reflected by all four approaches. Other studies have also taken into account the concentrations at deeper depths [60,76,84]. These concentration measurements at greater depth have a mathematical effect on the calculation of the concentration gradient at the soil-atmosphere interface although they have practically no influence at all on the actual concentration gradient at the soil-atmosphere interface. It could be shown that the inappropriate use of the EF approach can lead to substantial overestimation of the efflux estimates [76]. Thus, the consistency of the different calculation approaches in our case can be interpreted as a robustness or independence of the $\mathrm{CO}_{2}$ concentration gradient from the calculation approach, which is due to the shallow soil gas profile that focuses on the top $10 \mathrm{~cm}$ of the mineral soil and humus layer.

However, the four different approaches had a substantial effect on the estimation of the $\mathrm{CH}_{4}$ consumption (Figure 7, middle). Visual inspection of (Figure 7 left) shows that the more flexible LL and LS approaches can better fit the concentration data in the humus and yield a stronger $\mathrm{CH}_{4}$ gradient, and thus higher $\mathrm{CH}_{4}$ flux rates. The fits of EF and LR include all data that means also concentrations between 10 and $0 \mathrm{~cm}$ depths where obviously another $\mathrm{CH}_{4}$ gradient can be observed. The LL and LS approach yielded similar results (Figure 7, middle) and both approaches allow calculating soil gas fluxes at different depths. The LL approach however can be challenged more easily by soil gas profiles with weak gradients and outliers. We observed that under certain circumstances the LL approach yielded the same gradient in the humus layer as in the mineral soil with the regression functions shifted in parallel although a curvature was obvious in the entire soil gas profile. In such situations, the LS represented the overall curvature in a more realistic way, since it guarantees a continuous function. 

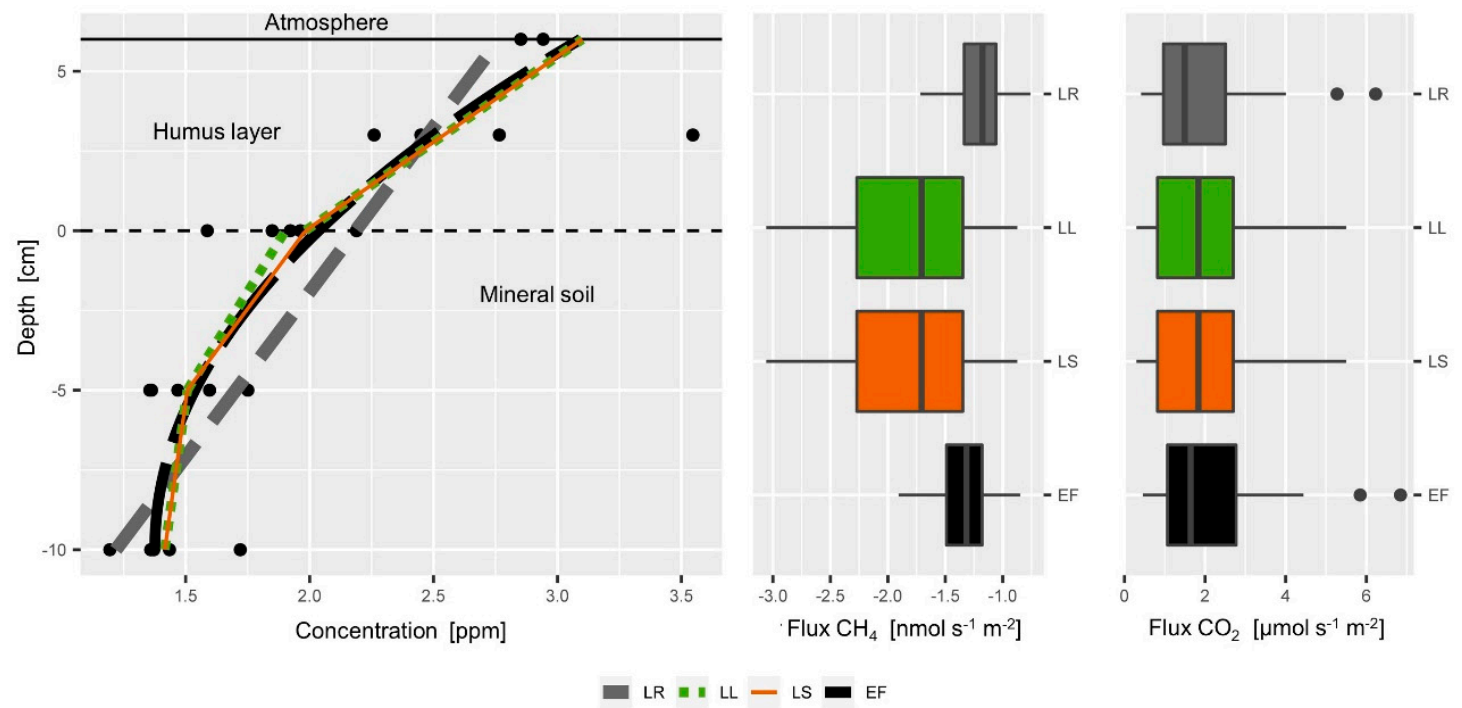

Figure 7. Comparison of different calculation approaches for the estimation of the soil-atmosphere gas flux. Left: Example of a typical soil $\mathrm{CH}_{4}$ profile. The lines of the Linear Regression (LR, grey, dashed), Exponential Function (EF, black, dashed) and the functions of the Local Linear approach (LL, green dotted) and the Linear Spline approach (LS, orange) yield different slopes at the soil surface. (Middle) $\mathrm{CH}_{4}$ consumption rates calculated by the LR and EF approach for our whole data set are much lower than the flux estimates of the LL and LS approach. Right: $\mathrm{CO}_{2}$ fluxes calculated by the LR and EF are slightly lower than fluxes calculated by the LL and LS approach.

\subsubsection{Vertical Partitioning of Soil Gas Fluxes}

We used the LL method to derive concentration gradients at different depth for $\mathrm{CO}_{2}$ and $\mathrm{CH}_{4}$ (Figure 6), which allows calculating vertical profiles of soil gas fluxes (Figure 8) and allocating the production and consumption of gases to a certain depth [44,60]. The increase in the $\mathrm{CO}_{2}$ flux between the 10 to $5 \mathrm{~cm}$ depth layer and the humus layer was extrapolated to the soil-atmosphere interface (Figure 8 left) as proposed by Hirano et al. [104]. $\mathrm{CO}_{2}$ flux between 10 to $5 \mathrm{~cm}$ depth was usually $<20 \%$ of the estimated efflux. Soil $\mathrm{CO}_{2}$ fluxes always increased towards the soil surface. The increase in the $\mathrm{CO}_{2}$ flux between the 5 to $0 \mathrm{~cm}$ depth layer and the humus layer was lower during the colder seasons (fall to spring) than in summer when the topsoil was warm. This higher soil respiration rate can be explained at least partly by the enhanced decomposition of organic material in the humus layer during summer. The top mineral soil and humus layer contributed the largest fraction of the total soil respiration as observed by others $[11,16,60,84]$. Future detailed analysis of the soil gas monitoring data will allow studying the temporal evolution of soil respiration in the mineral soil and the humus layer and their contribution to the total respiration. Such analysis holds the potential to better quantify the dynamics of the mineralization of the humus layer and better understand the $\mathrm{C}$ cycle in the soil.

The soil-atmosphere flux of $\mathrm{CH}_{4}$ was set to the estimated $\mathrm{CH}_{4}$ flux in the humus layer (Figure 8, right) since it can be expected that $\mathrm{CH}_{4}$ consumption in the top $\mathrm{cm}$ of the spruce litter does not contribute substantially to $\mathrm{CH}_{4}$ consumption [16,105]. The $\mathrm{CH}_{4}$ flux between 5 and $10 \mathrm{~cm}$ depth was very low, which corresponds to the very weak gradient compared to the gradient observed above (Figures 6 and 7 left). The negative soil $\mathrm{CH}_{4}$ fluxes increased almost linearly from the 10 to $5 \mathrm{~cm}$ depth to the humus layer during all seasons (Figure 8 right). More than $90 \%$ of the $\mathrm{CH}_{4}$ was consumed in the top $10 \mathrm{~cm}$ of the mineral soil. This corresponds to the observation that the topsoil is the most active $\mathrm{CH}_{4}$ consumer $[16,105]$. The $\mathrm{CH}_{4}$ flux profile showed an apparent seasonality with higher consumption rates in summer and fall than in winter, which resulted from the seasonal changes in soil moisture and soil gas diffusivity (Figures 6 and 7). 


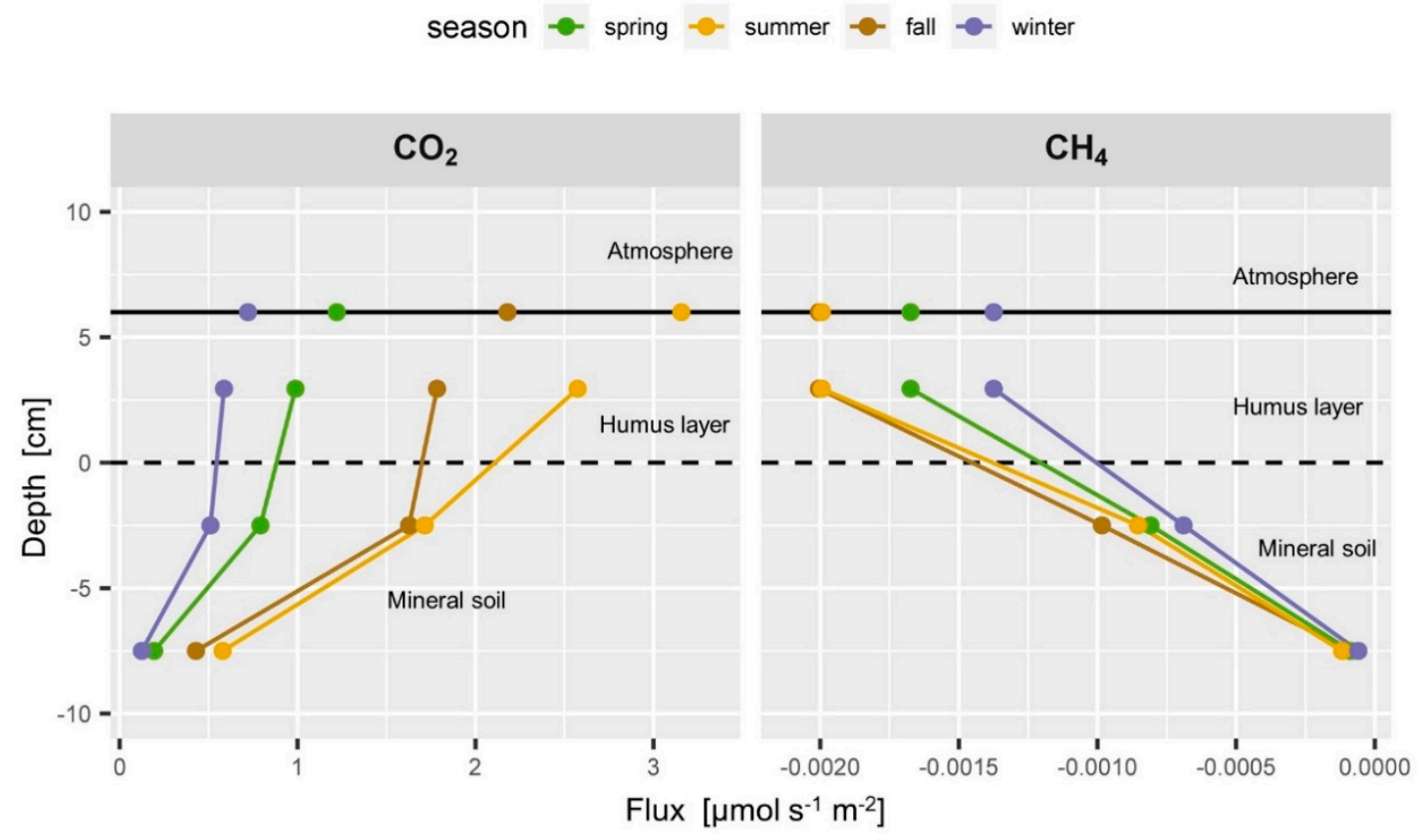

Figure 8. Typical seasonal flux profiles of $\mathrm{CO}_{2}$ (left) and $\mathrm{CH}_{4}$ (right). Soil $\mathrm{CO}_{2}$ flux is highest in summer in all depths with a large fraction coming from the topsoil $<-5 \mathrm{~cm}$ depth. The very linear $\mathrm{CH}_{4}$ flux profile changes only slightly throughout the seasons.

The soil $\mathrm{O}_{2}$ profiles did not allow using the LL or LS approach since they randomly yielded unrealistic flux estimates from time to time where $\mathrm{O}_{2}$ fluxes in the mineral horizon seemed to be higher than in the humus layer above. Reducing the degree of freedom by using the LR approach instead allowed stabilizing the estimation of the $\mathrm{O}_{2}$ gradient. This approach is suitable if the observed concentrations gradients are weak due to limited precision of the $\mathrm{O}_{2}$ measurements, and if the assumption of more or less linear gradients is justified based on prior knowledge. The comparison of the calculation approaches could show that the LR and LS approach yield very similar results for the estimation of the soil-atmosphere flux of $\mathrm{CO}_{2}$. Since $\mathrm{O}_{2}$ fluxes mainly counterbalance $\mathrm{CO}_{2}$ fluxes [115], it would be reasonable to assume that the LR approach is suitable for calculating the $\mathrm{O}_{2}$ gradient.

$\mathrm{N}_{2} \mathrm{O}$ data can also be characterized by problematic soil gas profiles that hardly exhibit significant concentration gradients, or profiles with very weak gradients (Figure 6, bottom) [16,76]. Even though $\mathrm{O}_{2}$ profiles and $\mathrm{N}_{2} \mathrm{O}$ profiles might yield a similar statistical result in terms of the quality of the regression (e.g., $\mathrm{R}^{2}$ ), they have to be interpreted differently. Production and consumption of $\mathrm{N}_{2} \mathrm{O}$ can occur on very small spatial scales [16], and even within aggregates and other hot spots [15], so that "noisy" $\mathrm{N}_{2} \mathrm{O}$ profiles are a result of really ongoing processes. $\mathrm{O}_{2}$ is primarily consumed by microbes and counterbalances soil respiration which originates more or less evenly distributed from the entire topsoil. We think that the scattering in the $\mathrm{O}_{2}$ profiles results to a larger extent from the lower precision of the measurement, which can be improved by repeated measurements (LR approach). Estimating surface fluxes of $\mathrm{N}_{2} \mathrm{O}$ includes thus a higher uncertainty than $\mathrm{O}_{2}$ fluxes although the estimation of their concentration gradients might yield a similar $\mathrm{R}^{2}$. As a consequence, we used the LS and LL approach for soil gas profiles that allowed calculating flux rates at different depths $\left(\mathrm{CO}_{2}\right.$ and $\mathrm{CH}_{4}$ ) and $\mathrm{LR}$ for the estimation of $\mathrm{O}_{2}$ fluxes which require a more robust approach. $\mathrm{N}_{2} \mathrm{O}$ fluxes were not calculated since the uncertainty requires additional quality assurance like comparative chamber measurements, which is currently planned. 


\subsection{Time Series and Interaction of Soil-Atmosphere Fluxes of $\mathrm{O}_{2}, \mathrm{CO}_{2}$ and $\mathrm{CH}_{4}$}

\subsubsection{Time Series Soil-Atmosphere Fluxes}

Soil-atmosphere fluxes of $\mathrm{O}_{2}$ and $\mathrm{CO}_{2}$ showed a strong seasonal behaviour (Figure 9) as observed from the soil gas profiles (Figure 5), with high flux rates during summer where temperatures were highest and soil moisture usually lowest (Figure 9). The time course of $\mathrm{O}_{2}$ seemed to reflect inversely the time course of $\mathrm{CO}_{2} . \mathrm{CO}_{2}$ emissions and $\mathrm{O}_{2}$ consumption reached from values close to zero up to approximately $6 \mu \mathrm{mol} \mathrm{m} \mathrm{m}^{-2} \mathrm{~s}^{-1}$, and had an average flux of $1.97 \mu \mathrm{mol} \mathrm{CO} \mathrm{CO}^{-2} \mathrm{~s}^{-1}$ and of $1.95 \mu \mathrm{mol} \mathrm{O} \mathrm{m}^{-2} \mathrm{~s}^{-1}$. This flux corresponds to $746 \mathrm{~g} \mathrm{C} \mathrm{m}^{-2} \mathrm{yr}^{-1}$ which is an average value for temperate forests [116,117].

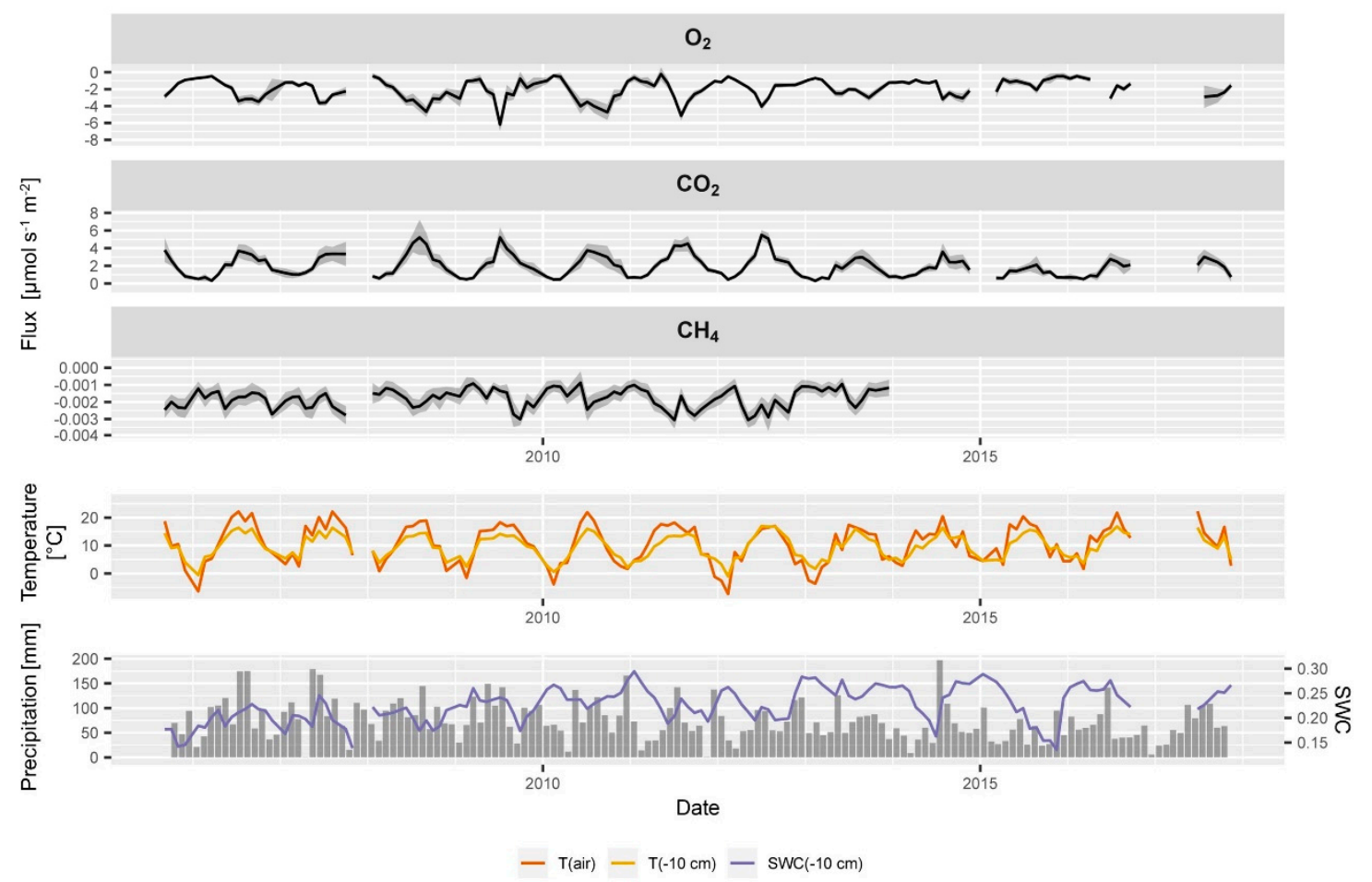

Figure 9. Time series of soil-atmosphere fluxes of $\mathrm{O}_{2}, \mathrm{CO}_{2}, \mathrm{CH}_{4}$, soil and air temperature, monthly rainfall and soil water content at $10 \mathrm{~cm}$ depth at the ES spruce plot. Uncertainty of the flux estimation is indicated in grey and is derived from the variability of the replications in the concentration profiles and the uncertainty in the estimation of the diffusivity. Please note the different scales on the $y$ axis for $\mathrm{O}_{2}, \mathrm{CO}_{2}$ and $\mathrm{CH}_{4}$.

Our soil respiration data represent an ideal base for further investigation e.g., the quantification of the effect of the environmental drivers such as soil temperature and soil moisture (Figure 9) [12,28] or the relationship between soil respiration and tree growth [37]. Working with the time series of all 13 soil gas monitoring plots will also allow comparing the effect of different trees, e.g., beech vs. spruce [117], and forest dynamics like thinning or drought effects.

Soil-atmosphere fluxes of $\mathrm{CH}_{4}$ showed more variability than soil $\mathrm{CH}_{4}$ concentrations, yet obvious seasonal cycles as observed with $\mathrm{CO}_{2}$ and $\mathrm{O}_{2}$ fluxes were not observed. Soil $\mathrm{CH}_{4}$ consumption ranged between 0.001 and $0.003 \mu \mathrm{mol} \mathrm{m}{ }^{-2} \mathrm{~s}^{-1}$, which is in the range of $\mathrm{CH}_{4}$ consumption rates observed in the region [41,72]. The average yearly consumption of $8.08 \mathrm{~kg} \mathrm{CH}_{4} \mathrm{ha}_{-1} \mathrm{yr}^{-1}$ corresponds to a high value (top 25\%) compared to temperate forest soils worldwide [18]. Future detailed analysis of the $\mathrm{CH}_{4}$ profiles and fluxes of all sites will allow studying the temporal evolution and long-term changes of $\mathrm{CH}_{4}$ consumption. This is of special interest since it is currently under debate that soils might be losing their capacity to consume atmospheric $\mathrm{CH}_{4}$ as recently observed by Ni and Groffman [118]. 
The uncertainty in the $\mathrm{CO}_{2}, \mathrm{O}_{2}$ and $\mathrm{CH}_{4}$ fluxes estimation changed over time (Figure 9) and resulted from the uncertainty in the gradient estimation and measurement of the soil water content. The uncertainty in $\mathrm{CO}_{2}$ and $\mathrm{O}_{2}$ fluxes seemed to be much smaller than in the $\mathrm{CH}_{4}$ fluxes which is due to the stronger gradients and less scattering in the data (Figures 6 and 7). The estimation of the uncertainty is not fully comparable between the $\mathrm{CO}_{2}$ and $\mathrm{O}_{2}$ fluxes since their calculation approach (LR vs. LL) was different and a different number of data points were used for the calculation of the gradient.

The relative contribution of the measurement uncertainty of the soil water content was constant over time, so that changes in the total uncertainty of flux estimates originate directly from the estimation of gradients in the gas concentration profiles. If the gradients in the respective soil gas profile become less distinct due to more scattering of the concentrations, the uncertainty in the flux estimation increases, e.g., the summer peak in soil $\mathrm{CO}_{2}$ efflux in 2013 (Figure 9). The uncertainty in the parameter estimates of the diffusivity model would be an additional source of uncertainty which was not included so far. In situ measurements of soil gas diffusivity would allow to assess the quality of the diffusivity models $[69,81]$ and improve the gradient based flux estimates. Additionally, chamber measurements next to the soil gas profiles would allow comparing and evaluating the gradient based flux estimates and also the diffusivity model [77].

\subsubsection{Relationship of $\mathrm{O}_{2}$ and $\mathrm{CO}_{2}$ Fluxes}

$\mathrm{O}_{2}$ and $\mathrm{CO}_{2}$ fluxes fell close to the diagonal -1:1 line (Figure 10), which means $\mathrm{O}_{2}$ fluxes and $\mathrm{CO}_{2}$ fluxes were well counterbalanced. Individual data points from winter and spring deviate substantially from the 1:1 line. This can be a result of a failure in the estimation of the $\mathrm{O}_{2}$ gradients, or can be an actual ongoing process [115]. The ratio of the soil $\mathrm{CO}_{2}$ efflux to the soil $\mathrm{O}_{2}$ flux can be addressed as apparent respiratory quotient (ARQ) [119]. ARQ is often close to $1[115,120]$ if transport mechanisms like the export of dissolved $\mathrm{CO}_{2}$ or other relevant processes such as intensive weathering of minerals in the soil can be ruled out. Studies found ARQ values $<0.7$ in Mediterranean ecosystems [119] and that even up to $2 / 3$ of the soil respiration can be lost via subsurface processes [121]. At the ES site soil respiration seemed to be well counterbalanced by an equimolar $\mathrm{O}_{2}$ flux so that $\mathrm{CO}_{2}$ losses due to subsurface processes can be ruled out. Dissolution of soil $\mathrm{CO}_{2}$ in soils with $\mathrm{pH}>7$ can play an important role $[9,83,119]$. Yet, the soil at the ES site is acidic and dissolution and export of soil $\mathrm{CO}_{2}$ via percolating water plays only a negligible role.

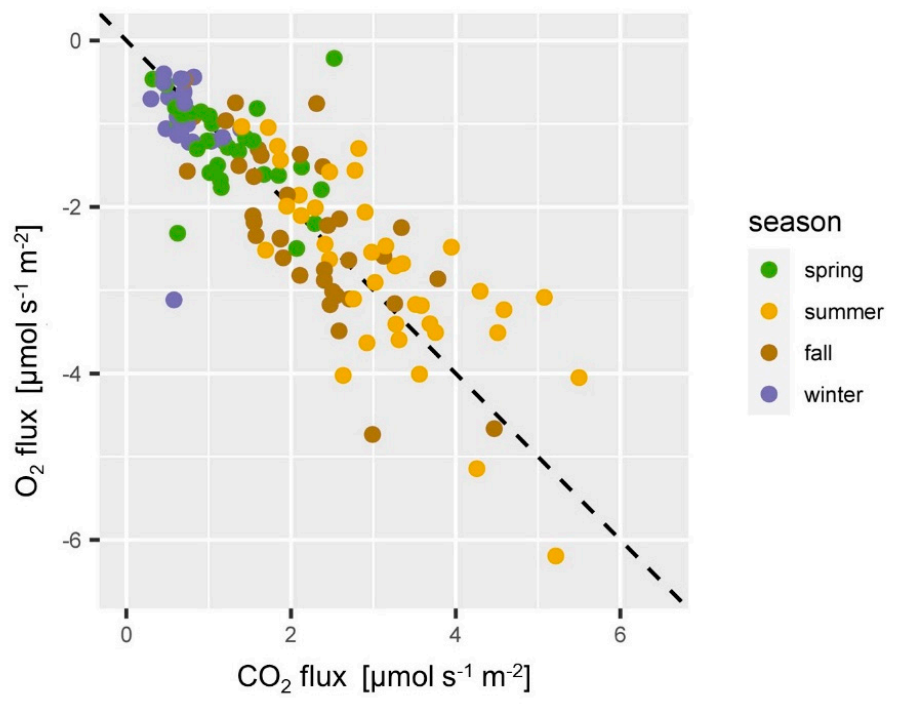

Figure 10. Relationship of $\mathrm{O}_{2}$ and $\mathrm{CO}_{2}$ fluxes at the ES spruce site. $\mathrm{CO}_{2}$ emission and $\mathrm{O}_{2}$ consumption fall close to the diagonal 1:-1 line in most of the cases and were highest in summer (yellow) and lowest in winter (blue). 
Future detailed analysis of soil gas monitoring data will allow studying ARQ to evaluate the relevance of subsurface processes at the different sites. Studying the temporal evolution of ARQ and $\mathrm{O}_{2}$ concentrations might give new insights into processes at temporarily waterlogged soils which may become anoxic for a certain time [120].

\section{Conclusions}

We introduced an experimental set-up and design for long term soil gas monitoring. Typical soil gas profiles and fluxes of one of 13 monitoring plots were presented to discuss the specifications, advantages, and drawbacks of the system. Several passive gas samplers per depth were used which allows a precise assignment of the sampling locations. This is a prerequisite for the assessment of the homogeneity of the soil gas profile and the quantification and qualification of the estimates of the soil gas fluxes. The samplers do not require electrical power or intensive maintenance and affect the soil surface only minimally which makes them ideal for long term monitoring. The soil gas samplers allow efficient and highly reproducible handling of the gas samples which is essential for a good quality assurance. The subsequent GC analysis was optimized for the purpose and additional gas analysis can be included. These features make the set-up an efficient, versatile, flexible, and reliable tool which is suitable for long-term monitoring of soil gas profiles.

The monitoring routine is scheduled from biweekly to monthly measurements for practical reasons. Such a schedule is suitable to cover seasonal cycles which are known for soil $\mathrm{CO}_{2}, \mathrm{O}_{2}$ and $\mathrm{CH}_{4}$. The routine schedule is a drawback for occasional event-based soil gas dynamics such as $\mathrm{N}_{2} \mathrm{O}$ fluxes that are dominated by peak events. While $\mathrm{CO}_{2}, \mathrm{O}_{2}$, and $\mathrm{CH}_{4}$ fluxes can be reliably estimated based on their concentration profile, $\mathrm{N}_{2} \mathrm{O}$ fluxes are more difficult to estimate especially when $\mathrm{N}_{2} \mathrm{O}$ soil concentration gradients are weak and indicating concurrent production and consumption of $\mathrm{N}_{2} \mathrm{O}$ at the same time within the profile. Future campaigns with chamber measurements could provide reference values of gas fluxes that can help to eliminate or minimize sources of uncertainty and add additional value to our data.

The long-term soil gas profile data of 13 forest plots and the ongoing monitoring and evaluation holds the potential to answer various research questions. It is the ideal data basis to study (a) the linkage between soil respiration, tree growth and forest productivity, (b) the interaction and drivers of soil gas fluxes of $\mathrm{CO}_{2}, \mathrm{CH}_{4}$ and $\mathrm{N}_{2} \mathrm{O}$, (c) the relationship of $\mathrm{CO}_{2}$ and $\mathrm{O}_{2}$ fluxes and potential interfering processes such as anoxic conditions, (d) the interaction between concurrent production and consumption of $\mathrm{N}_{2} \mathrm{O}$, and (e) appearance and drivers of $\mathrm{C}_{2} \mathrm{H}_{4}$ in forest soils. The continuity of the existing long term records soil gas data in combination with the ICP Forest Level 2 monitoring program are the ideal basis for further ecophysiological studies related to soil processes in which soil gases are produced or consumed.

Author Contributions: M.M. conceived and designed the manuscript and presentation of results; M.M. and V.G. conducted the data analysis. A.S. conducted the measurements and contributed in the technical section describing the gas analysis. M.M. and V.L. wrote the paper. All authors have read and agreed to the published version of the manuscript.

Funding: This research received no external funding.

Acknowledgments: We would like to thank our colleagues H. Buberl, M. Wehrle, C. v. Fürstenberg, A. Schupp for the gas sampling and maintenance of the monitoring sites. We would like to thank K. v. Wilpert for his initiative to start the soil gas monitoring program, A. Hölscher for the management of the monitoring sites, A. Bär and B. Burget for the development of the samplers, H. Puhlmann for the soil water modelling, and all who contributed to the development and maintenance of the system.

Conflicts of Interest: The authors declare no conflict of interest. 


\section{References}

1. Wang, B.; Brewer, P.E.; Shugart, H.H.; Lerdau, M.T.; Allison, S.D. Soil aggregates as biogeochemical reactors and implications for soil-atmosphere exchange of greenhouse gases-A concept. Glob. Chang. Biol. 2019, 25, 373-385. [CrossRef] [PubMed]

2. Chesworth, W. Encyclopedia of Soil Science; Springer: Dorderecht, The Netherlands, 2009; p. 902.

3. Smith, K.A.; Ball, T.; Conen, F.; Dobbie, K.E.; Rey, A. Exchange of greenhouse gases between soil and atmosphere: Interactions of soil physical factors and biological processes. Eur. J. Soil Sci. 2018, 69, 2-4. [CrossRef]

4. $\quad$ IPCC. Climate Change 2013: The Physical Science Basis. Contribution of Working Group I to the Fifth Assessment Report of the Intergovernmental Panel on Climate Change; IPCC: Cambridge, UK; New York, NY, USA, 2013.

5. Conrad, R. Soil microorganisms as controllers of atmospheric trace gases $\left(\mathrm{H}_{2}, \mathrm{CO}, \mathrm{CH}_{4}, \mathrm{OCS}_{2} \mathrm{~N}_{2} \mathrm{O}\right.$, and $\left.\mathrm{NO}\right)$. Microbiol. Rev. 1996, 60, 609-640. [CrossRef] [PubMed]

6. Sánchez-Cañete, E.P.; Kowalski, A.S.; Serrano-Ortiz, P.; Pérez-Priego, O.; Domingo, F. Deep $\mathrm{CO}_{2}$ soil inhalation/exhalation induced by synoptic pressure changes and atmospheric tides in a carbonated semiarid steppe. Biogeosciences 2013, 10, 6591-6600. [CrossRef]

7. NOAA. Global Monitoring Laboratory Earth System Research Laboratories. Available online: https: //www.esrl.noaa.gov/gmd/ccgg/trends/ (accessed on 22 November 2020).

8. Ryan, M.G.; Law, B.E. Interpreting, measuring, and modeling soil respiration. Biogeochemistry 2005, 73, 3-27. [CrossRef]

9. Maier, M.; Schack-Kirchner, H.; Hildebrand, E.E.; Schindler, D. Soil $\mathrm{CO}_{2}$ efflux vs. soil respiration: Implications for flux models. Agric. Meteorol. 2011, 151, 1723-1730. [CrossRef]

10. Chen, L.; Liu, L.; Qin, S.; Yang, G.; Fang, K.; Zhu, B.; Kuzyakov, Y.; Chen, P.; Xu, Y.; Yang, Y. Regulation of priming effect by soil organic matter stability over a broad geographic scale. Nat. Commun. 2019, 10, 5112. [CrossRef]

11. Goffin, S.; Aubinet, M.; Maier, M.; Plain, C.; Schack-Kirchner, H.; Longdoz, B. Characterization of the soil $\mathrm{CO}_{2}$ production and its carbon isotope composition in forest soil layers using the flux-gradient approach. Agr. Met. 2014, 188, 45-57. [CrossRef]

12. Davidson, E.A.; Janssens, I.A. Temperature sensitivity of soil carbon decomposition and feedbacks to climate change. Nature 2006, 440, 165-173. [CrossRef]

13. Conrad, R. Soil microbial processes involved in production and consumption of atmospheric trace gases. Adv. Microb. Ecol. 1995, 14, 207-250.

14. Smith, K.A.; Ball, T.; Conen, F.; Dobbie, K.E.; Massheder, J.; Rey, A. Exchange of greenhouse gases between soil and atmosphere: Interactions of soil physical factors and biological processes. Eur. J. Soil Sci. 2003, 54, 779-791. [CrossRef]

15. Kuzyakov, Y.; Blagodatskaya, E. Microbial hotspots and hot moments in soil: Concept \& review. Soil Biol. Biochem. 2015, 83, 184-199. [CrossRef]

16. Maier, M.; Longdoz, B.; Laemmel, T.; Schack-Kirchner, H.; Lang, F. 2D profiles of $\mathrm{CO}_{2}, \mathrm{CH}_{4}, \mathrm{~N}_{2} \mathrm{O}$ and gas diffusivity in a well aerated soil: Measurement and Finite Element Modeling. Agr. Met. 2017, 247, 21-33. [CrossRef]

17. Von Fischer, J.C.; Hedin, L.O. Separating methane production and consumption with a field-based isotope pool dilution technique. Glob. Biogeochem. Cycles 2002, 16, 8-1-8-13. [CrossRef]

18. Dutaur, L.; Verchot, L.V. A global inventory of the soil $\mathrm{CH}_{4}$ sink. Glob. Biogeochem. Cycles 2007, 21. [CrossRef]

19. Chapuis-Lardy, L.; Wrage, N.; Metay, A.; Chotte, J.-L.; Bernoux, M. Soils, a sink for $\mathrm{N}_{2} \mathrm{O}$ : A review. Glob. Chang. Biol. 2007, 13, 1-17. [CrossRef]

20. Davidson, E.A.; Verchot, L.V. Testing the Hole-in-the-Pipe Model of nitric and nitrous oxide emissions from soils using the TRAGNET Database. Glob. Biogeochem. Cycles 2000, 14, 1035-1043. [CrossRef]

21. Ingwersen, J.; Butterbach-Bahl, K.; Gasche, R.; Richter, O.; Papen, H. Barometric Process Separation: New Method for Quantifying Nitrification, Denitrification, and Nitrous Oxide Sources in Soils. Soil Sci. Soc. Am. J. 1999, 63, 117-128. [CrossRef]

22. Well, R.; Maier, M.; Lewicka-Szczebak, D.; Köster, J.-R.; Ruoss, N. Underestimation of denitrification rates from field application of the ${ }^{15} \mathrm{~N}$ gas flux method and its correction by gas diffusion modelling. Biogeosciences 2019, 16, 2233-2246. [CrossRef] 
23. Smith, A.M. Ethylene in Soil Biology. Annu. Rev. Phytopathol. 1976, 14, 53-73. [CrossRef]

24. Neljubow, D. Über die horizontale Nutation der Stengel von Pisum sativa und einiger Anderer Pflanzen. Beih. Bot. Cent. 1901, 10, 128-139.

25. Arshad, M.; Frankenberger, W.T. Ethylene in Soil; Springer: Boston, MA, USA, 2002; pp. 139-193. [CrossRef]

26. Jackson, M.B. Ethylene and Responses of Plants to Soil Waterlogging and Submergence. Annu. Rev. Plant Physiol. 1985, 36, 145-174. [CrossRef]

27. Zechmeister-Boltenstern, S.; Smith, K.A. Ethylene production and decomposition in soils. Biol. Fertil. Soils 1998, 26, 354-361. [CrossRef]

28. Davidson, E.A.; Belk, E.; Boone, R.D. Soil water content and temperature as independent or confounded factors controlling soil respiration in a temperate mixed hardwood forest. Glob. Chang. Biol. 1998, 4, 217-227. [CrossRef]

29. Goffin, S.; Wylock, C.; Haut, B.; Maier, M.; Longdoz, B.; Aubinet, M. Modeling soil $\mathrm{CO}_{2}$ production and transport to investigate the intra-day variability of surface efflux and soil $\mathrm{CO}_{2}$ concentration measurements in a Scots Pine Forest (Pinus Sylvestris, L.). Plant Soil 2015, 390, 195-211. [CrossRef]

30. Conant, R.T.; Dalla-Betta, P.; Klopatek, C.C.; Klopatek, J.M. Controls on soil respiration in semiarid soils. Soil Biol. Biochem. 2004, 36, 945-951. [CrossRef]

31. Luo, G.J.; Kiese, R.; Wolf, B.; Butterbach-Bahl, K. Effects of soil temperature and moisture on methane uptake and nitrous oxide emissions across three different ecosystem types. Biogeosciences 2013, 10, 3205-3219. [CrossRef]

32. Luo, G.; Brüggemann, N.; Wolf, B.; Gasche, R.; Grote, R.; Butterbach-Bahl, K. Decadal variability of soil $\mathrm{CO}_{2}$, $\mathrm{NO}, \mathrm{N}_{2} \mathrm{O}$, and $\mathrm{CH}_{4}$ fluxes at the Höglwald Forest, Germany. Biogeosciences 2012, 9, 1741-1763. [CrossRef]

33. Subke, J.-A.; Moody, C.S.; Hill, T.C.; Voke, N.; Toet, S.; Ineson, P.; Teh, Y.A. Rhizosphere activity and atmospheric methane concentrations drive variations of methane fluxes in a temperate forest soil. Soil Biol. Biochem. 2018, 116, 323-332. [CrossRef]

34. Keller, M.; Varner, R.; Dias, J.D.; Silva, H.; Crill, P.; de Oliveira, R.C.; Asner, G.P. Soil-Atmosphere Exchange of Nitrous Oxide, Nitric Oxide, Methane, and Carbon Dioxide in Logged and Undisturbed Forest in the Tapajos National Forest, Brazil. Earth Interact. 2005, 9, 1-28. [CrossRef]

35. Fest, B.; Wardlaw, T.; Livesley, S.J.; Duff, T.J.; Arndt, S.K. Changes in soil moisture drive soil methane uptake along a fire regeneration chronosequence in a eucalypt forest landscape. Glob. Chang. Biol. 2015, 21, 4250-4264. [CrossRef] [PubMed]

36. Wolf, B.; Chen, W.; Brüggemann, N.; Zheng, X.; Pumpanen, J.; Butterbach-Bahl, K. Applicability of the soil gradient method for estimating soil-atmosphere $\mathrm{CO}_{2}, \mathrm{CH}_{4}$, and $\mathrm{N}_{2} \mathrm{O}$ fluxes for steppe soils in Inner Mongolia. J. Plant Nutr. Soil Sci. 2011, 174, 359-372. [CrossRef]

37. Janssens, I.A.; Lankreijer, H.; Matteucci, G.; Kowalski, A.S.; Buchmann, N.; Epron, D.; Pilegaard, K.; Kutsch, W.; Longdoz, B.; Grunwald, T.; et al. Productivity overshadows temperature in determining soil and ecosystem respiration across European forests. Glob. Chang. Biol. 2001, 7, 269-278. [CrossRef]

38. Smith, K.A.; Dobbie, K.E.; Ball, B.C.; Bakken, L.R.; Sitaula, B.K.; Hansen, S.; Brumme, R.; Borken, W.; Christensen, S.; Priemé, A.; et al. Oxidation of atmospheric methane in Northern European soils, comparison with other ecosystems, and uncertainties in the global terrestrial sink. Glob. Chang. Biol. 2000, 6, 791-803. [CrossRef]

39. Dore, S.; Fry, D.L.; Stephens, S.L. Spatial heterogeneity of soil $\mathrm{CO}_{2}$ efflux after harvest and prescribed fire in a California mixed conifer forest. Ecol. Manag. 2014, 319, 150-160. [CrossRef]

40. Darenova, E.; Pavelka, M.; Macalkova, L. Spatial heterogeneity of $\mathrm{CO}_{2}$ efflux and optimization of the number of measurement positions. Eur. J. Soil Biol. 2016, 75, 123-134. [CrossRef]

41. Maier, M.; Cordes, M.; Osterholt, L. Soil respiration and $\mathrm{CH}_{4}$ consumption covary on the plot scale. Geoderma 2021, 382, 114702. [CrossRef]

42. Maier, M.; Paulus, S.; Nicolai, C.; Stutz, K.; Nauer, P. Drivers of Plot-Scale Variability of $\mathrm{CH}_{4}$ Consumption in a Well-Aerated Pine Forest Soil. Forests 2017, 8, 193. [CrossRef]

43. Sabrekov, A.F.; Glagolev, M.V.; Fastovets, I.A.; Smolentsev, B.A.; Il'yasov, D.V.; Maksyutov, S.S. Relationship of methane consumption with the respiration of soil and grass-moss layers in forest ecosystems of the southern taiga in Western Siberia. Eurasian Soil Sci. 2015, 48, 841-851. [CrossRef]

44. Maier, M.; Schack-Kirchner, H. Using the gradient method to determine soil gas flux: A review. Agric. For. Meteorol. 2014, 192-193, 78-95. [CrossRef] 
45. Kühne, A.; Schack-Kirchner, H.; Hildebrand, E.E. Gas diffusivity in soils compared to ideal isotropic porous media. J. Plant Nutr. Soil Sci. 2012, 175, 34-45. [CrossRef]

46. Lange, S.F.; Allaire, S.E.; Rolston, D.E. Soil-gas diffusivity in large soil monoliths. Eur. J. Soil Sci. 2009, 60, 1065-1077. [CrossRef]

47. Pavelka, M.; Acosta, M.; Kiese, R.; Altimir, N.; Brümmer, C.; Crill, P.; Longdoz, B.; Ortiz, S. Standardisation of chamber technique for $\mathrm{CO}_{2}, \mathrm{~N}_{2} \mathrm{O}$ and $\mathrm{CH}_{4}$ fluxes measurements from terrestrial ecosystems. Int. Agrophys. 2018, 32, 569-587. [CrossRef]

48. Massman, W.J.; Lee, X. Eddy covariance flux corrections and uncertainties in long-term studies of carbon and energy exchanges. Agric. Meteorol. 2002, 113, 121-144. [CrossRef]

49. Davidson, E.A.; Savage, K.; Verchot, L.V.; Navarro, R. Minimizing artifacts and biases in chamber-based measurements of soil respiration. Agric. Meteorol. 2002, 113, 21-37. [CrossRef]

50. De Jong, E.; Schappert, H.J.V. Calculation of Soil Respiration and Activity From $\mathrm{CO}_{2}$ Profiles in the Soil. Soil Sci. 1972, 113, 328-333. [CrossRef]

51. Baldocchi, D.D. Assessing the eddy covariance technique for evaluating carbon dioxide exchange rates of ecosystems: Past, present and future. Glob. Chang. Biol. 2003, 9, 479-492. [CrossRef]

52. Lundegardh, H. Carbon dioxide evolution of soil and crop growth. Soil Sci. 1927, 23, 417-453. [CrossRef]

53. Hutchinson, G.L.; Livingston, G.P. Vents and seals in non-steady-state chambers used for measuring gas exchange between soil and the atmosphere. Eur. J. Soil Sci. 2001, 52, 675-682. [CrossRef]

54. Livingston, G.P.; Hutchinson, G.L.; Spartalian, K. Trace Gas Emission in Chambers. Soil Sci. Soc. Am. J. 2006, 70, 1459. [CrossRef]

55. Pumpanen, J.; Kolari, P.; Ilvesniemi, H.; Minkkinen, K.; Vesala, T.; Niinistö, S.; Lohila, A.; Larmola, T.; Morero, M.; Pihlatie, M.; et al. Comparison of different chamber techniques for measuring soil $\mathrm{CO}_{2}$ efflux. Agric. Meteorol. 2004, 123, 159-176. [CrossRef]

56. Pihlatie, M.K.; Christiansen, J.R.; Aaltonen, H.; Korhonen, J.F.J.; Nordbo, A.; Rasilo, T.; Benanti, G.; Giebels, M.; Helmy, M.; Sheehy, J.; et al. Comparison of static chambers to measure $\mathrm{CH}_{4}$ emissions from soils. Agric. Meteorol. 2013, 171-172, 124-136. [CrossRef]

57. Hogberg, P.; Nordgren, A.; Buchmann, N.; Taylor, A.F.; Ekblad, A.; Hogberg, M.N.; Nyberg, G.; Ottosson-Lofvenius, M.; Read, D.J. Large-scale forest girdling shows that current photosynthesis drives soil respiration. Nature 2001, 411, 789-792. [CrossRef] [PubMed]

58. Maier, M.; Mayer, S.; Laemmel, T. Rain and wind affect chamber measurements. Agric. Meteorol. 2019, 279, 107754. [CrossRef]

59. Hillel, D. Fundamentals of Soil Physics; Academic Press: New York, NY, USA, 1980; p. 413.

60. Davidson, E.A.; Savage, K.E.; Trumbore, S.E.; Borken, W. Vertical partitioning of $\mathrm{CO}_{2}$ production within a temperate forest soi. Glob. Chang. Biol. 2006, 12, 944-956. [CrossRef]

61. de Jong, E.; Redmann, R.E.; Ripley, E.A. A Comparison of Methods To Measure Soil Respiration. Soil Sci. 1979, 127, 300-306. [CrossRef]

62. Pumpanen, J.; Ilvesniemi, H.; Kulmala, L.; Siivola, E.; Laakso, H.; Kolari, P.; Helenelund, C.; Laakso, M.; Uusimaa, M.; Hari, P. Respiration in boreal forest soil as determined from carbon dioxide concentration profile. Soil Sci. Soc. Am. J. 2007, 72, 1187-1196. [CrossRef]

63. Vargas, R.; Allen, M.F. Dynamics of Fine Root, Fungal Rhizomorphs, and Soil Respiration in a Mixed Temperate Forest: Integrating Sensors and Observations. Vadose Zone J. 2008, 7, 1055-1064. [CrossRef]

64. Tang, J.; Baldocchi, D.D.; Qi, Y.; Xu, L. Assessing soil $\mathrm{CO}_{2}$ efflux using continuous measurements of $\mathrm{CO}_{2}$ profiles in soils with small solid-state sensors. Agric. Meteorol. 2003, 118, 207-220. [CrossRef]

65. Maier, M.; Schack-Kirchner, H.; Hildebrand, E.E.; Holst, J. Pore-space $\mathrm{CO}_{2}$ dynamics in a deep, well-aerated soil. Eur. J. Soil Sci. 2010, 61, 877-887. [CrossRef]

66. Seok, B.; Helmig, D.; Williams, M.W.; Liptzin, D.; Chowanski, K.; Hueber, J. An automated system for continuous measurements of trace gas fluxes through snow: An evaluation of the gas diffusion method at a subalpine forest site, Niwot Ridge, Colorado. Biogeochemistry 2009, 95, 95-113. [CrossRef]

67. Pihlatie, M.; Pumpanen, J.; Rinne, J.; Ilvesniemi, H.; Simojoki, A.; Hari, P.; Vesala, T. Gas concentration driven fluxes of nitrous oxide and carbon dioxide in boreal forest soil. Tellus B Chem. Phys. Meteorol. 2007, 59, 458-469. [CrossRef] 
68. Goffin, S.; Longdoz, B.; Maier, M.; Schack-Kirchner, H.; Aubinet, M. Soil Respiration in forest Ecosystems: Combination of a multilayer Approach and an Isotopic Signal Analysis. Commun. Agric. Appl. Biol. Sci. 2012, 72, 139-144.

69. Laemmel, T.; Maier, M.; Schack-Kirchner, H.; Lang, F. An in situ method for real-time measurement of gas transport in soil. Eur. J. Soil Sci. 2017, 68, 156-166. [CrossRef]

70. Parent, F.; Plain, C.; Epron, D.; Maier, M.; Longdoz, B. A new method for continuously measuring the $\delta^{13} \mathrm{C}$ of soil $\mathrm{CO}_{2}$ concentrations at different depths by laser spectrometry. Eur. J. Soil Sci. 2013, 64, 516-525. [CrossRef]

71. Kammann, C.; Grünhage, L.; Jäger, H.J. A new sampling technique to monitor concentrations of $\mathrm{CH}_{4}, \mathrm{~N}_{2} \mathrm{O}$ and $\mathrm{CO}_{2}$ in air at well-defined depths in soils with varied water potential. Eur. J. Soil Sci. 2001, 52, 297-303. [CrossRef]

72. Maier, M.; Machacova, K.; Lang, F.; Svobodova, K.; Urban, O. Combining soil and tree-stem flux measurements and soil gas profiles to understand $\mathrm{CH}_{4}$ pathways in Fagus sylvatica forests. J. Plant Nutr. Soil Sci. 2018, 181, 31-35. [CrossRef]

73. Vicca, S.; Bahn, M.; Estiarte, M.; van Loon, E.E.; Vargas, R.; Alberti, G.; Ambus, P.; Arain, M.A.; Beier, C.; Bentley, L.P.; et al. Can current moisture responses predict soil $\mathrm{CO}_{2}$ efflux under altered precipitation regimes? A synthesis of manipulation experiments. Biogeosci. Discuss. 2014, 11, 853-899. [CrossRef]

74. Vargas, R.; Allen, M.F. Environmental controls and the influence of vegetation type, fine roots and rhizomorphs on diel and seasonal variation in soil respiration. New Phytol. 2008, 179, 460-471. [CrossRef]

75. Warlo, H.; Machacova, K.; Nordstrom, N.; Maier, M.; Laemmel, T.; Roos, A.; Schack-Kirchner, H. Comparison of portable devices for sub-ambient concentration measurements of methane $\left(\mathrm{CH}_{4}\right)$ and nitrous oxide $\left(\mathrm{N}_{2} \mathrm{O}\right)$ in soil research. Int. J. Environ. Anal. Chem. 2018, 98, 1030-1037. [CrossRef]

76. Schack-Kirchner, H.; Kublin, E.; Hildebrand, E.E. Finite-Element Regression to Estimate Production Profiles of Greenhouse Gases in Soils. Vadose Zone J. 2011, 10, 169-183. [CrossRef]

77. Sánchez-Cañete, E.P.; Scott, R.L.; van Haren, J.; Barron-Gafford, G.A. Improving the accuracy of the gradient method for determining soil carbon dioxide efflux. J. Geophys. Res. Biogeosci. 2017, 122, 50-64. [CrossRef]

78. Schack-Kirchner, H.; Hildebrand, E.E.; von Wilpert, K. Ein konvektionsfreies Sammelsystem für Bodenluft-Soil gas sampling avoiding mass-flow. Z. Für Pflanz. Und Bodenkd. 1993, 156, 307-310. [CrossRef]

79. Levintal, E.; Dragila, M.I.; Kamai, T.; Weisbrod, N. Free and forced gas convection in highly permeable, dry porous media. Agric. Meteorol. 2017, 232, 469-478. [CrossRef]

80. Maier, M.; Schack-Kirchner, H.; Aubinet, M.; Goffin, S.; Longdoz, B.; Parent, F. Turbulence Effect on Gas Transport in Three Contrasting Forest Soils. Soil Sci. Soc. Am. J. 2012, 76, 1518-1528. [CrossRef]

81. Laemmel, T.; Mohr, M.; Longdoz, B.; Schack-Kirchner, H.; Lang, F.; Schindler, D.; Maier, M. From above the forest into the soil-How wind affects soil gas transport through air pressure fluctuations. Agric. Meteorol. 2019, 265, 424-434. [CrossRef]

82. Sánchez-Cañete, E.P.; Kowalski, A.S. Comment on "Using the gradient method to determine soil gas flux: A review" by M. Maier and H. Schack-Kirchner. Agric. Meteorol. 2014, 197, 254-255. [CrossRef]

83. Flechard, C.R.; Neftel, A.; Jocher, M.; Ammann, C.; Leifeld, J.; Fuhrer, J. Temporal changes in soil pore space $\mathrm{CO}_{2}$ concentration and storage under permanent grassland. Agric. Meteorol. 2007, 142, 66-84. [CrossRef]

84. Jassal, R.; Black, A.; Novak, M.; Morgenstern, K.; Nesic, Z.; Gaumont-Guay, D. Relationship between soil $\mathrm{CO}_{2}$ concentrations and forest-floor $\mathrm{CO}_{2}$ effluxes. Agric. Meteorol. 2005, 130, 176-192. [CrossRef]

85. Troeh, F.R.; Jabro, J.D.; Kirkham, D. Gaseous diffusion equations for porous materials. Geoderma 1982, $239-253$. [CrossRef]

86. Moldrup, P.; Olesen, T.; Gamst, J.; Schjønning, P.; Yamaguchi, T.; Rolston, D.E. Predicting the Gas Diffusion Coefficient in Repacked Soil: Water-Induced Linear Reduction Model. Soil Sci. Soc. Am. J. 2000, 64, 1588-1594. [CrossRef]

87. Penman, H.L. Gas and vapour movements in the soil: I. The diffusion of vapours through porous solids. J. Agric. Sci. 1940, 30, 437. [CrossRef]

88. Millington, R. Gas diffusion in porous media. Science 1959, 130, 100-102. [CrossRef] [PubMed]

89. Deepagoda, T.; Moldrup, P.; Schjønning, P.; Jonge, L.W.d.; Kawamoto, K.; Komatsu, T. Density-corrected models for gas diffusivity and air permeability in unsaturated soil. Vadose Zone J. 2011, 10, 226-238. [CrossRef] 
90. Thorbjørn, A.; Moldrup, P.; Blendstrup, H.; Komatsu, T.; Rolston, D.E. A Gas Diffusivity Model Based on Air-, Solid-, and Water-Phase Resistance in Variably Saturated Soil. Vadose Zone J. 2008, 7, 1276. [CrossRef]

91. Moldrup, P.; Olesen, T.; Yoshikawa, S.; Komatsu, T.; Rolston, D.E. Predictive-descriptive models for gas and solute diffusion coefficients in variably saturated porous media coupled to pore-size distribution: II. Gas diffusivity in undisturbed soil. Soil Sci. 2005, 170, 867-880. [CrossRef]

92. Maier, M.; Lang, V. Gas Diffusivity in the Forest Humus Layer. Soil Sci. 2019, 184, 13-16. [CrossRef]

93. Massman, W.J. A review of the molecular diffusivities of $\mathrm{H}_{2} \mathrm{O}, \mathrm{CO}_{2}, \mathrm{CH}_{4}, \mathrm{CO}, \mathrm{O}_{3}, \mathrm{SO}_{2}, \mathrm{NH}_{3}, \mathrm{~N}_{2} \mathrm{O}, \mathrm{NO}$, and $\mathrm{NO}_{2}$ in air, $\mathrm{O}_{2}$ and $\mathrm{N}_{2}$ near STP. Atmos. Environ. 1998, 32, 1111-1127. [CrossRef]

94. Hammel, K.; Kennel, M. Charakterisierung und Analyse der Wasserverfügbarkeit und des Wasserhaushalts von Waldstandorten in Bayern Mit Dem Simulationsmodell BROOK90; Heinrich Frank: München, Germany, 2001; Volume 185, p. 148.

95. Shuttleworth, W.J.; Wallace, J. Evaporation from sparse crops-an energy combination theory. Q. J. R. Meteorol. Soc. 1985, 111, 839-855. [CrossRef]

96. van Genuchten, M.T. A Closed-form Equation for Predicting the Hydraulic Conductivity of Unsaturated Soils. Soil Sci. Soc. Am. J. 1980, 44, 892-898. [CrossRef]

97. Mualem, Y. A new model for predicting the hydraulic conductivity of unsaturated porous media. Water Resour. Res. 1976, 12, 513-522. [CrossRef]

98. Richards, L.A. Capillary Conduction of Liquids through Porous Mediums. Physics 1931, 1,318-333. [CrossRef]

99. Federer, C.A.; Vörösmarty, C.; Fekete, B. Sensitivity of Annual Evaporation to Soil and Root Properties in Two Models of Contrasting Complexity. J. Hydrometeorol. 2003, 4, 1276-1290. [CrossRef]

100. Federer, C. BROOK90: A Simulation Model for Evaporation, Soil Water, and Streamflow. 1995. Available online: http://www.ecoshift.net/brook/brook90.htm (accessed on 22 November 2020).

101. Schmidt-Walter, P.; Ahrends, B.; Mette, T.; Puhlmann, H.; Meesenburg, H. NFIWADS: The water budget, soil moisture, and drought stress indicator database for the German National Forest Inventory (NFI). Ann. For. Sci. 2019, 76, 39. [CrossRef]

102. Tang, J.; Baldocchi, D.D.; Xu, L. Tree photosynthesis modulates soil respiration on a diurnal time scale. Glob. Chang. Biol. 2005, 11, 1298-1304. [CrossRef]

103. Turcu, V.E.; Jones, S.B.; Or, D. Continuous Soil Carbon Dioxide and Oxygen Measurements and Estimation of Gradient-Based Gaseous Flux. Vadose Zone J. 2005, 4, 1161-1169. [CrossRef]

104. Hirano, T. Long-term half-hourly measurement of soil $\mathrm{CO}_{2}$ concentration and soil respiration in a temperate deciduous forest. J. Geophys. Res. 2003, 108. [CrossRef]

105. Borken, W.; Davidson, E.A.; Savage, K.; Sundquist, E.T.; Steudler, P. Effect of summer throughfall exclusion, summer drought, and winter snow cover on methane fluxes in a temperate forest soil. Soil Biol. Biochem. 2006, 38, 1388-1395. [CrossRef]

106. R Core Team. R: A Language and Environment for Statistical Computing; R Foundation for Statistical Computing: Vienna, Austria, 2019.

107. Gómez-Rubio, V. ggplot2-Elegant Graphics for Data Analysis (2nd Edition). J. Stat. Softw. $2017,77$. [CrossRef]

108. Wickham, H.; François, R.; Henry, L.; Müller, K. dplyr: A Grammar of Data Manipulation. R package Version 1.0.2; 2020. Available online: https://github.com/tidyverse/dplyr/ (accessed on 22 November 2020).

109. Bund-Länder-AG. Forstliches Umweltmonitoring in Deutschland; Bundesministerium für Ernährung und Landwirtschaft: Berlin, Germany, 2016; p. 39.

110. The World Reference Base for Soil Resources (WRB). International Soil Classification System for Naming Soils and Creating Legends for Soil Maps. World Soil Resources Reports No. 106; FAO: Rome, Italy, 2015.

111. Clough, T.J.; Rochette, P.; Thomas, S.M.; Pihlatie, M.; Christiansen, J.R.; Thorman, R.E. Global Research Alliance $\mathrm{N}_{2} \mathrm{O}$ chamber methodology guidelines: Design considerations. J. Env. Qual. 2020, 49, 1081-1091. [CrossRef]

112. Schack-Kirchner, H. (Ed.) Struktur und Gashaushalt von Waldböden; Ber. Forschungszentrum Waldökosysteme: Göttingen, Germany, 1994; Volume 112, p. 145.

113. Franco-Luesma, S.; Cavero, J.; Plaza-Bonilla, D.; Cantero-Martínez, C.; Tortosa, G.; Bedmar, E.J.; Álvaro-Fuentes, J. Irrigation and tillage effects on soil nitrous oxide emissions in maize monoculture. Agron. J. 2020, 112, 56-71. [CrossRef] 
114. Warlo, H.; von Wilpert, K.; Lang, F.; Schack-Kirchner, H. Black Alder (Alnus glutinosa (L.) Gaertn.) on Compacted Skid Trails: A Trade-off between Greenhouse Gas Fluxes and Soil Structure Recovery? Forests 2019, 10, 726. [CrossRef]

115. Seibt, U.; Brand, W.A.; Heimann, M.; Lloyd, J.; Severinghaus, J.P.; Wingate, L. Observations of O2:CO2exchange ratios during ecosystem gas exchange. Glob. Biogeochem. Cycles 2004, 18. [CrossRef]

116. Bond-Lamberty, B.; Thomson, A. A global database of soil respiration data. Biogeosciences 2010, 7, $1915-1926$. [CrossRef]

117. Borken, W.; Xu, Y.-J.; Davidson, E.A.; Beese, F. Site and temporal variation of soil respiration in European beech, Norway spruce, and Scots pine forests. Glob. Chang. Biol. 2002, 8, 1205-1216. [CrossRef]

118. Ni, X.; Groffman, P.M. Declines in methane uptake in forest soils. Proc. Natl. Acad. Sci. USA 2018, 115, 8587-8590. [CrossRef]

119. Angert, A.; Yakir, D.; Rodeghiero, M.; Preisler, Y.; Davidson, E.A.; Weiner, T. Using $\mathrm{O}_{2}$ to study the relationships between soil $\mathrm{CO}_{2}$ efflux and soil respiration. Biogeosciences 2015, 12, 2089-2099. [CrossRef]

120. Hodges, C.; Kim, H.; Brantley, S.L.; Kaye, J. Soil $\mathrm{CO}_{2}$ and $\mathrm{O}_{2}$ Concentrations Illuminate the Relative Importance of Weathering and Respiration to Seasonal Soil Gas Fluctuations. Soil Sci. Soc. Am. J. 2019, 83, 1167-1180. [CrossRef]

121. Sanchez-Canete, E.P.; Barron-Gafford, G.A.; Chorover, J. A considerable fraction of soil-respired $\mathrm{CO}_{2}$ is not emitted directly to the atmosphere. Sci. Rep. 2018, 8, 13518. [CrossRef]

Publisher's Note: MDPI stays neutral with regard to jurisdictional claims in published maps and institutional affiliations. 